\title{
Oxygen and strontium isotopes as provenance indicators of fish at archaeological sites: the case study of Sagalassos, SW Turkey
}

\author{
Elise Dufour ${ }^{\mathrm{a}, *}$, Chris Holmden ${ }^{\mathrm{a}}$, Wim Van Neer ${ }^{\mathrm{b}, \mathrm{c}}$, Antoine Zazzo ${ }^{\mathrm{a}, 1}$, \\ William P. Patterson ${ }^{a}$, Patrick Degryse ${ }^{\mathrm{d}}$, Eddy Keppens ${ }^{\mathrm{e}}$ \\ ${ }^{a}$ Saskatchewan Isotope Laboratory, Department of Geological Sciences, University of Saskatchewan, 114 Science Place, Saskatoon, SK S7N 5E2, Canada \\ ${ }^{\mathrm{b}}$ Royal Belgian Institute of Natural Sciences, Rue Vautier 29, B-1000 Brussels, Belgium \\ ${ }^{\mathrm{c}}$ Katholieke Universiteit Leuven, Laboratory of Comparative Anatomy and Biodiversity, Ch. Deberiotstraat 32, B-3000 Leuven, Belgium \\ ${ }^{\mathrm{d}}$ Katholieke Universiteit Leuven, Center for Archaeological Sciences, Section Geology, Celestijnenlaan 200E, B-3001 Leuven, Belgium \\ ${ }^{\mathrm{e}}$ Vrije Universiteit Brussel, Isotope Geology and the Evolution of the Environment, Department of Geology, Pleinlaan 2, B-1050 Brussels, Belgium
}

Received 7 June 2006; received in revised form 28 September 2006; accepted 20 October 2006

\begin{abstract}
In this paper, we investigate the potential use of oxygen and strontium isotope ratios $\left(\delta^{18} \mathrm{O}_{\mathrm{p}}\right.$ and $\left.{ }^{87} \mathrm{Sr} /{ }^{86} \mathrm{Sr}\right)$ measured in archaeological fish enamel as provenance indicators. $\delta^{18} \mathrm{O}_{\mathrm{p}}$ and ${ }^{87} \mathrm{Sr} /{ }^{86} \mathrm{Sr}$ were measured in a suite of archaeological carp remains recovered from the Anatolian townsite of Sagalassos dated to the Early Byzantine period (AD 450-650) and compared to that of modern fish, river and lake waters from the Anatolian region. We used sequential leaches in weak acetic acid to remove diagenetic Sr from fossil tooth enamel, monitoring the effectiveness of this approach by measuring the $\mathrm{Sr} / \mathrm{Ca}$ ratios of the leachates via an isotope dilution thermal ionization mass spectrometry method (ID-TIMS). $\delta^{18} \mathrm{O}_{\mathrm{p}}$ values mostly excluded a riverine origin. ${ }^{87} \mathrm{Sr} /{ }^{86} \mathrm{Sr}$ ratios of one fish overlapped with the ${ }^{87} \mathrm{Sr} /{ }^{86} \mathrm{Sr}$ signatures of two lakes in the Anatolian region, and at least one lake (Gölcük) could be removed as a candidate owing to a very distinctive ${ }^{87} \mathrm{Sr} /{ }^{86} \mathrm{Sr}$ signature not found in any of the fish remains. Most of the tooth samples analyzed could not be assigned a precise geographical origin since the ${ }^{87} \mathrm{Sr} /{ }^{86} \mathrm{Sr}$ ratios measured in enamel did not match that of any of the local lakes selected as potential origin. This result suggests that carp may have originated from lakes that have not yet been sampled, although this conclusion is not supported by other archaeological evidence. Alternatively, the lack of correspondence between lakes and fish $\mathrm{Sr}$ isotope ratios highlights several possible sources of uncertainties including spatial heterogeneity in ${ }^{87} \mathrm{Sr} /{ }^{86} \mathrm{Sr}$ ratio within a lake, the contribution of dietary strontium to the ${ }^{87} \mathrm{Sr} /{ }^{86} \mathrm{Sr}$ ratio of fish tooth enamel, and post-mortem alteration of the tooth $\mathrm{Sr}$ isotope signal during fossilization. In spite of the high precision of the strontium isotope analyses and the wide range of variation in the surface waters of the Anatolian lakes and rivers, this method may remain limited to distinguishing between lakes situated in regions of bedrock of very distinct age and geology until these sources of uncertainty are more fully investigated.
\end{abstract}

(C) 2006 Elsevier Ltd. All rights reserved.

Keywords: Oxygen isotope ratios; Strontium isotope ratios; Carp; Tooth enamel; Environmental markers; Trading; Turkey

\footnotetext{
* Corresponding author at present address: Institut de Recherche pour le Développement, UR055 "PALEOTROPIQUE", Centre IRD d'Ile-de-France, 32 rue Henri Varagnat, 93143 Bondy Cedex, France. Tel.: +331480259 83; fax: +33148025554.

E-mail address: elise.dufour@bondy.ird.fr (E. Dufour).

${ }^{1}$ Present address: School of Biology and Environmental Sciences, Agriculture and Food Science Centre, University College Dublin, Belfield, Dublin 4, Ireland.
}

\section{Introduction}

Documenting the origin of imported food items such as fish is essential to identify former trade connections (Van Neer et al., 2004). The classical town of Sagalassos is located in western Anatolia (Turkey) approximately $110 \mathrm{~km}$ north of the coastal town of Antalya (Fig. 1). Archaeological excavations of Roman and Early Byzantine contexts, dating between the 1 st and 7 th century $\mathrm{AD}$, yielded abundant fish remains 


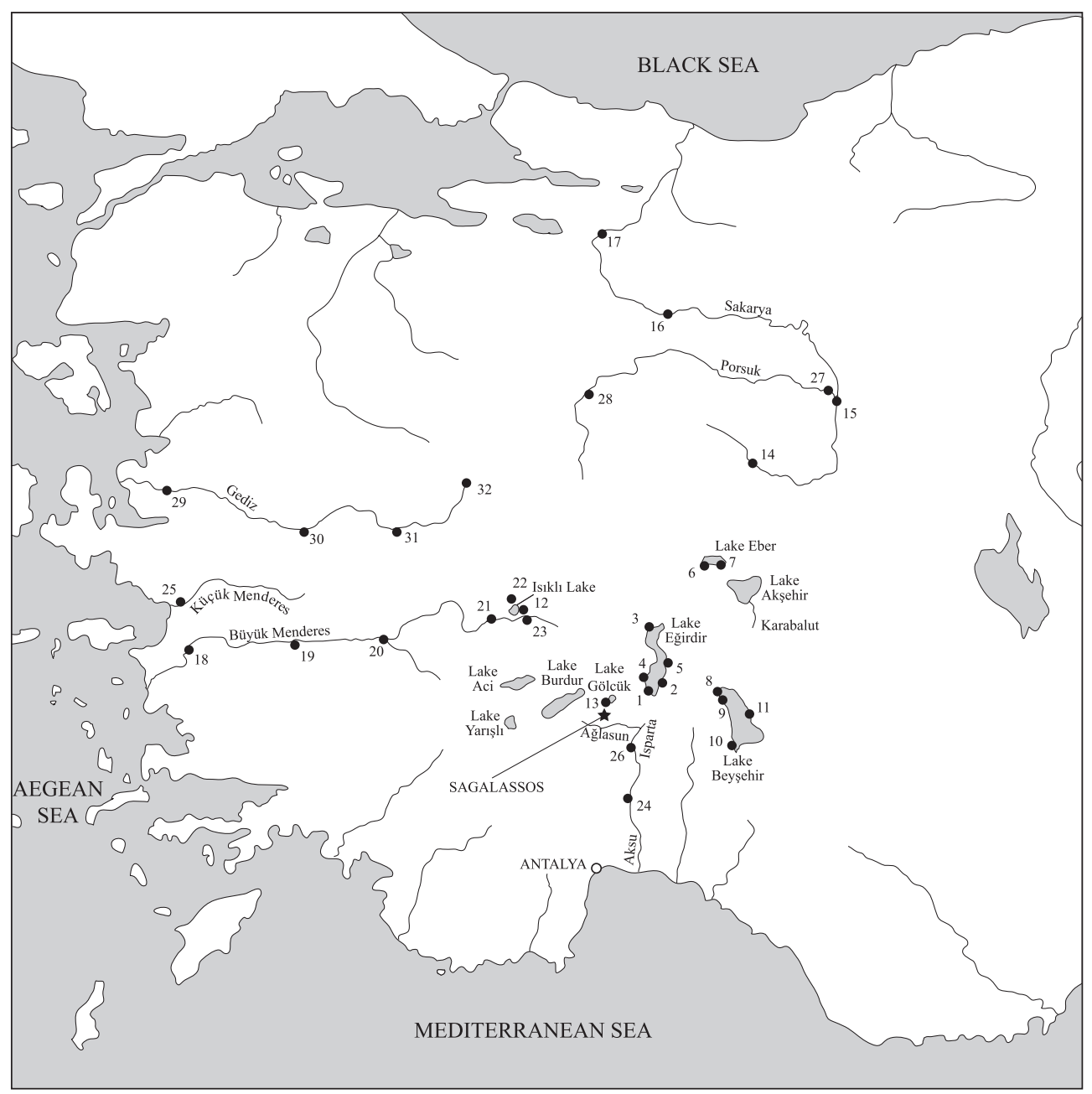

Fig. 1. Map of Anatolia showing the locations of the sampling sites.

belonging to at least 17 species (Van Neer et al., 1997, 2004). None of the fish species found at Sagalassos are native to the local river Ağlasun (Van Neer et al., 2000a) and therefore must have been imported. Fish can be grouped into three broad categories based on their origin: Anatolian freshwater, exotic freshwater, and Mediterranean (Van Neer et al., 1997, 2000b, 2004). In some cases the geographic distribution of species permits determination of provenance, sometimes with high precision, as in the case of the cicek (Pseudophoxinus handlirschii) a small cyprinid that is endemic to Eğirdir Lake (Geldiay and Balık, 1996), located $\sim 35 \mathrm{~km}$ from Sagalassos. Conversely, the wild carp (Cyprinus carpio), an Anatolian species that dominates the fish remains recovered at Sagalassos (Van Neer et al., 1997) has a very wide distribution. Literature data (e.g., Geldiay and Balık, 1996) and results from surveys carried out between 1996 and 1999 in Anatolian waters (Van Neer et al., 2000a; in press) permit reconstruction of the ancient carp distribution. Today, domesticated carps have been introduced into numerous reservoirs impounded by modern dams where the species was not previously present. In other locations the pre-existing wild form was gradually replaced by continuous stocking. Taking the natural distribution of species into account, the wild carp found at Sagalassos may have been imported from several large lakes (Eğirdir Lake, Beyşehir Lake, Akşehir or Eber Lake) or rivers (Büyük Menderes, Gediz, Sakarya, Küçük Menderes, Porsuk) situated to the north, west, or east of Sagalassos. Because of the widespread occurrence of carp in Anatolian lakes and rivers it is possible that the fishes consumed by the people of Sagalassos came from many different local sources. Alternatively, it is possible that most of the fish were captured from a single lake, or from a specific location within a lake. This information could lead to inferences regarding the scale of fishing activity and, therefore, the importance of a fisheries industry to the local Anatolian economy.

One approach to connecting fish remains with their origin is through the analysis of mitochondrial DNA, by comparing fossils and modern populations of fish from various areas. This technique was successfully applied to Clarias gariepinus, an exotic freshwater species found at Sagalassos (Arndt et al., 2003). Comparison of ancient and modern haplotypes indicates a lower Nile origin of $C$. gariepinus consumed at Sagalassos. Because modern carp stocking in Turkey has diluted natural genetic structuring, DNA analysis cannot be used to determine origin. Instead, this study aims to establish the geographic origin of carp consumed in Sagalassos using 
phosphate oxygen isotope values $\left(\delta^{18} \mathrm{O}_{\mathrm{p}}\right)$ and strontium isotope ratios $\left({ }^{87} \mathrm{Sr} /{ }^{86} \mathrm{Sr}\right)$ measured in carp enamel apatite.

Biogenic apatites are comprised of a mineral fraction consisting of calcium phosphate hydroxyapatite $\left(\mathrm{Ca}_{10}\right.$ $\left.\left(\mathrm{PO}_{4}\right)_{6}(\mathrm{OH})_{2}\right)$. Measurements of $\delta^{18} \mathrm{O}_{\mathrm{p}}$ values and ${ }^{87} \mathrm{Sr} /{ }^{86} \mathrm{Sr}$ ratios in the inorganic fraction of archaeological mammal teeth and bones have become established methods in palaeoecological and palaeobiological research. The two tracers have been used for the study of seasonal mobility, population dynamics and habitat utilization by prehistoric populations (Balasse et al., 2002; Bentley and Knipper, 2005; Hoogewerff et al., 2001; Knudson et al., 2005; Price et al., 2000; Schweissing and Grupe, 2003; White et al., 1998), procurement distance for construction timber and food (Benson et al., 2003; Reynolds et al., 2005) or migration of ancient elephant populations (Hoppe et al., 1999). However, the approach has never been used to document the former exploitation of aquatic resources. The use of isotope ratios in biogenic apatites as provenance indicators in archaeological remains is based on the following: (1) isotope ratios of an organism's tissues record that of the environment of growth, (2) different geographical origins can be discriminated because they present sufficient variation in isotopic signatures, and (3) the isotope value of a tissue is preserved during fossilization. In this paper, we examine for the first time the potential of $\delta^{18} \mathrm{O}_{\mathrm{p}}$ values and ${ }^{87} \mathrm{Sr} /{ }^{86} \mathrm{Sr}$ ratios in archaeological fish tooth enamel as a proxy for the geographical origin of fish. First, we produce a modern database for $\delta^{18} \mathrm{O}_{\mathrm{p}}$ values and ${ }^{87} \mathrm{Sr} /{ }^{86} \mathrm{Sr}$ ratios of fish teeth and waters from various lakes and rivers that are potential points of origin of the archaeological fish. Second, we applied sequential leaches of bioapatites in weak acetic acid in order to remove diagenetic $\mathrm{Sr}$ from fossil enamel (Holmden and Hudson, 2003; Hoppe et al., 2003). Results obtained in modern settings were then compared to those obtained from archaeological fish teeth in order to determine whether the $\delta^{18} \mathrm{O}_{\mathrm{p}}$ values and ${ }^{87} \mathrm{Sr} /{ }^{86} \mathrm{Sr}$ ratios can be used as provenance indicators and whether this approach makes it possible to discriminate among potential origins of carp consumed in Sagalassos.

\section{Background}

\subsection{Environmental controls on $\delta^{18} \mathrm{O}$ and \\ ${ }^{87} \mathrm{Sr} /{ }^{86} \mathrm{Sr}$ in fish teeth}

$\delta^{18} \mathrm{O}_{\mathrm{p}}$ values of fish enamel are a function of temperature and the oxygen isotope ratio $\left(\delta^{18} \mathrm{O}_{\mathrm{w}}\right)$ of ambient water (Longinelli and Nuti, 1973). $\delta^{18} \mathrm{O}_{\mathrm{w}}$ values of lake water are directly tied to the water balance and origin. Lakes receive water from rivers, sheet runoff, groundwater, and precipitation. $\delta^{18} \mathrm{O}_{\mathrm{w}}$ values of lakes are often slightly higher than the input river or precipitation $\delta^{18} \mathrm{O}_{\mathrm{w}}$ values due to evaporation. The degree of ${ }^{18} \mathrm{O}$ enrichment depends on the amount of evaporation. Because different lakes will have a different complement of isotopically distinct input waters, and different water residence times, variation in $\delta^{18} \mathrm{O}_{\mathrm{w}}$ values between lakes is expected. This natural variance in lake water $\delta^{18} \mathrm{O}_{\mathrm{w}}$ values may be sufficient to match the archaeological fish remains to the lakes from which they were caught based on $\delta^{18} \mathrm{O}_{\mathrm{P}}$ values of tooth enamel. If the lakes are too similar in isotope value, use of $\delta^{18} \mathrm{O}_{\mathrm{p}}$ values for fingerprinting lake provenances will be compromised. Additionally, temperature variability can complicate assessment of $\delta^{18} \mathrm{O}_{\mathrm{w}}$ values from $\delta^{18} \mathrm{O}_{\mathrm{p}}$ values. For example, a $1 \%$ difference in measured $\delta^{18} \mathrm{O}_{\mathrm{p}}$ value is equivalent to $4.3{ }^{\circ} \mathrm{C}$ difference in temperature. Therefore, differences of up to about $4 \%$ in the measured $\delta^{18} \mathrm{O}_{\mathrm{p}}$ values could be due to seasonal differences in the water temperature of a single lake, rather than differences in $\delta^{18} \mathrm{O}_{\mathrm{w}}$ values between lakes. Rivers sourced at high elevations tend to have lower $\delta^{18} \mathrm{O}_{\mathrm{w}}$ values due to lower $\delta^{18} \mathrm{O}_{\mathrm{w}}$ values of precipitation at high altitude than rivers sourced at lower altitudes, due to lower $\delta^{18} \mathrm{O}_{\mathrm{w}}$ values of precipitation at high altitude. Therefore, in mountainous regions like the study area, alpine rivers may have lower $\delta^{18} \mathrm{O}_{\mathrm{w}}$ values than precipitation at lower elevations.

Strontium substitutes for calcium in different sites within hydroxyapatite. The $\mathrm{Sr}$ incorporated into calcified fish tissues is derived from habitat water and diet (Farrell and Campana, 1996; Kennedy et al., 2000; Simkiss, 1974). In contrast to oxygen isotopes there is no temperature fractionation of $\mathrm{Sr}$ isotopes between water and bioapatites and, as such, the measured ${ }^{87} \mathrm{Sr} /{ }^{86} \mathrm{Sr}$ ratio in fish hydroxyapatites directly reflects the ${ }^{87} \mathrm{Sr} /{ }^{86} \mathrm{Sr}$ of the fish habitat water and diet (Kennedy et al., 1997, 2000).

The ${ }^{87} \mathrm{Sr} /{ }^{86} \mathrm{Sr}$ ratio of rivers is derived from the weathering of bedrock in the catchment through which the river flows. The isotope balance of $\mathrm{Sr}$ dissolved in lakes reflects the ${ }^{87} \mathrm{Sr} /{ }^{86} \mathrm{Sr}$ and $\mathrm{Sr}$ concentration of rivers and groundwater inputs. If lakes are well mixed, isotopically distinct inputs of $\mathrm{Sr}$ from rivers, groundwater and precipitation, will be homogenized and lake water ${ }^{87} \mathrm{Sr} /{ }^{86} \mathrm{Sr}$ ratios should be fairly uniform, with the exception of river mouths. The Anatolian region is a tectonically complex package of many types of igneous, volcanic and sedimentary rocks. Upthrusted Mezozoic and Cenozoic limestones $\left({ }^{87} \mathrm{Sr} /{ }^{86} \mathrm{Sr}\right.$ ranges from 0.7075 to 0.7092$)$ and mafic volcanic rocks (characterized by low ${ }^{87} \mathrm{Sr} /{ }^{86} \mathrm{Sr}$ of $\sim 0.703-$ 0.706) are common in this region. Because each of these rock types contains significant amounts of $\mathrm{Sr}$ and weathers easily, Sr released from these rocks will dominate $\mathrm{Sr}$ budgets of surficial waters of the region. Moreover, granites and other acid igneous and volcanic rocks, together with metamorphosed clastic sedimentary rocks also occurring in the area, have higher $\mathrm{Rb}$ contents and thus higher ${ }^{87} \mathrm{Sr} /{ }^{86} \mathrm{Sr}$ ratios $(>0.710)$. Because of these differences in lithology and geological ages of bedrock in riverine and lacustrine catchment areas, different ${ }^{87} \mathrm{Sr} /{ }^{86} \mathrm{Sr}$ signatures are expected for different lakes and rivers in the Anatolian region.

\subsection{Post-mortem alteration of ${ }^{87} \mathrm{Sr} /{ }^{86} \mathrm{Sr}$ and $\delta^{18} \mathrm{O}_{p}$ biogenic signatures in fish tooth enamel}

Several mechanisms result in modification of oxygen and strontium isotope ratios of biogenic apatite including: (1) precipitation of secondary minerals within and at the surface of the bioapatite crystals; (2) isotopic exchange during dissolution/reprecipitation processes; and (3) adsorption of ions at 
sites on the surface of crystals and their subsequent diffusion into the bioapatite. The relative importance of these different mechanisms depends in part on the physico-chemical properties of the bioapatite. Bone and dentine are relatively porous and contain $\sim 30 \%$ (dry weight) organic matter, and the mineral fraction is composed of small and highly reactive hydroxyapatite crystals. High porosity and solubility allow increased water/mineral interactions favouring extensive post-mortem geochemical changes in bone and dentine (Wang and Cerling, 1994). We chose to conduct analyses on enamel because it is less porous than bone or dentine being composed of larger, more tightly packed crystals with smaller amounts intercrystalline organic matter ( $\leq 2 \%)$ (Driessens and Verbeeck, 1990), thus reducing permeability to diagenetic fluids. Although isotopic alterations cannot be excluded a priori in fossil enamel they are usually orders of magnitude lower than in bone and dentine. Therefore, enamel is considered the material of choice for paleoenvironmental reconstructions.

Phosphate oxygen isotope alteration in fossil apatite may occur during dissolution and reprecipitation of apatite if the $\mathrm{P}-\mathrm{O}$ bond is broken by microbes utilizing the phosphorous as a nutrient. Otherwise, the solubility of apatite is so low that O-exchange between phosphate oxygen and water under abiotic conditions has little effect on the $\delta^{18} \mathrm{O}_{\mathrm{p}}$ value of phosphates even at geological time scales (Blake et al., 1997; Lécuyer et al., 1999; Zazzo et al., 2004a,b). Given the low solubility and porosity of enamel apatite, $\delta^{18} \mathrm{O}_{\mathrm{p}}$ values can be considered as pristine in the vast majority of fossil settings.

Although more limited than in bone or dentine, post-mortem diffusion of diagenetic strontium into tooth enamel may occur during fossilization (Holmden et al., 1996; Hoppe et al., 2003; Koch et al., 1992; Martin and Scher, 2004). Soil pore fluids tend to have higher $\mathrm{Sr} / \mathrm{Ca}$ ratios than surface waters due to the formation of pedogenic carbonate and anhydrite. The formation of these calcium bearing soil minerals discriminates against $\mathrm{Sr}$, allowing the $\mathrm{Sr} / \mathrm{Ca}$ ratio of the soil pore fluids to increase. This process creates a chemical potential gradient that will drive the diffusion of soil mineral $\mathrm{Sr}$ into tooth enamel. Because the ${ }^{87} \mathrm{Sr} /{ }^{86} \mathrm{Sr}$ signature of the soil minerals is likely different to the lakes from which the fish were caught, this contaminant needs to be removed before the original biogenic signature of ${ }^{87} \mathrm{Sr} /{ }^{86} \mathrm{Sr}$ in the enamel can be revealed. It has been demonstrated that diagenetic $\mathrm{Sr}$ penetrates the enamel from the surface of the tooth (Holmden et al., 1996). In tooth cross-section the contaminant Sr concentration is found to be highest in the outer enamel layers, dropping off rapidly with distance into the interior enamel layers, thus, giving the appearance of a diffusion profile. The Sr profile is evidence of post-mortem $\mathrm{Sr}$ enrichment of the tooth enamel, although some enrichment in the outer layers of tooth enamel may also occur during the life of the organism, most likely due to $\mathrm{Sr}$ adsorption from ingested water and from food during mastication. It is assumed that when the tooth first erupts the $\mathrm{Sr}$ content of the tooth is uniform throughout and that in the case of fish, the original ${ }^{87} \mathrm{Sr} /{ }^{86} \mathrm{Sr}$ signature of the tooth reflects the diet of the parent, which in turn reflects the ${ }^{87} \mathrm{Sr} /{ }^{86} \mathrm{Sr}$ ratio of the dissolved $\mathrm{Sr}$ reservoir of the lake.
Although dietary $\mathrm{Sr}$ absorption during mastication can reinforce the environmental signature of the lake in the tooth enamel of the fish, it is not possible to separate this source of $\mathrm{Sr}$ from diagenetically derived $\mathrm{Sr}$ absorption occurring post-mortem in the midden. Therefore, in order to reveal the original environmental signature of ${ }^{87} \mathrm{Sr} /{ }^{86} \mathrm{Sr}$ in the tooth, the diffusion profile must be removed. Fortunately, this can be accomplished with sequential leaches in a weak acid (Holmden et al., 1996). The effectiveness of this strategy for the recovery of the original ${ }^{87} \mathrm{Sr} /{ }^{86} \mathrm{Sr}$ biological values has been demonstrated for fossil shark teeth (Elliott et al., 1998) and mammal teeth (Hoppe et al., 2003). Hoppe et al. (2003) showed that sequential leaching in weak acid removed more than $95 \%$ of the diagenetic Sr contamination from Holocene and Miocene enamel, whereas when the same treatment was applied to bones between 15 and $80 \%$ of the diagenetic $\mathrm{Sr}$ remained.

One of the practical problems with sequential leaching is to know how much leaching is needed to remove the diffusion profile. Too much leaching lowers analyte concentrations, thus, making $\mathrm{Sr}$ isotope analysis more difficult, whereas not enough leaching can yield mixtures of biologically and diagenetically derived $\mathrm{Sr}$ whose ${ }^{87} \mathrm{Sr} /{ }^{86} \mathrm{Sr}$ ratios will have no environmental significance. In this paper, we use measurements of enamel $\mathrm{Sr} / \mathrm{Ca}$ ratios as an index by which to judge the extent to which the $\mathrm{Sr}$ diffusion profile in the tooth has been removed. Because in most cases diagenetic fluids will have higher $\mathrm{Sr} / \mathrm{Ca}$ ratios than those that were originally preserved in the bioapatite of the fish tooth enamel, progress towards removing the diffusion profile with sequential leaches can be monitored by tracking leach progress on a plot of $\mathrm{Sr} / \mathrm{Ca}$ ratio versus leach number. As the diffusion profile is stripped away, the $\mathrm{Sr} / \mathrm{Ca}$ ratio of successive leaches decreases, until eventually a constant $\mathrm{Sr} / \mathrm{Ca}$ ratio is achieved (the plateau region of the curve). Because the organism of a fish discriminates against strontium during tooth formation, fish tooth apatite is lower in $\mathrm{Sr} / \mathrm{Ca}$ than the habitat waters. Therefore, the $\mathrm{Sr} / \mathrm{Ca}$ ratio of the plateau region of the curve is interpreted as the $\mathrm{Sr} / \mathrm{Ca}$ ratio of the tooth when it first erupted. This will differ from the $\mathrm{Sr} / \mathrm{Ca}$ ratio of the lake by a $\mathrm{Sr}$-discrimination factor, but the ${ }^{87} \mathrm{Sr} /{ }^{86} \mathrm{Sr}$ ratio of this 'plateau' $\mathrm{Sr}$ is not fractionated in relation to the environmental sources of $\mathrm{Sr}$ and, thus, will reflect lake water and dietary $\mathrm{Sr}$ sources.

\section{Materials and methods}

\subsection{Lake water sampling and isotopic analysis}

Water samples representing a broad range of potential lacustrine and riverine environments for the Sagalassos carp were collected in Nalgene ${ }^{\mathrm{TM}}$ bottles during the summers of 2001, 2002, 2003 and 2005 (Table 1). Aliquots taken for ${ }^{87} \mathrm{Sr} /{ }^{86} \mathrm{Sr}$ analysis were acidified to $\mathrm{pH}$ of $\leq 2$. Determination of $\delta^{18} \mathrm{O}_{\mathrm{w}}$ values for 2000, 2001 and 2002 water samples were performed in the Department of Geology of the Free University of Brussels (VUB) (Belgium) using a Finnigan MAT Delta $\mathrm{E}$ isotope ratio mass spectrometer with dual inlet 
Table 1

$\delta^{18} \mathrm{O}$ values $\left(\delta^{18} \mathrm{O}_{\mathrm{w}}, \%\right.$ VSMOW) and ${ }^{87} \mathrm{Sr} /{ }^{86} \mathrm{Sr}$ ratios of lake and river water from Anatolia

\begin{tabular}{|c|c|c|c|c|c|}
\hline Locality & & Coordinates & & $\delta^{18} \mathrm{O}$ VSMOW & ${ }^{86} \mathrm{Sr} /{ }^{87} \mathrm{Sr}$ \\
\hline \multicolumn{6}{|c|}{ Ĕ̈irdir Lake } \\
\hline 1 & Eğirdir town & $3752480 \mathrm{~N} 3051550 \mathrm{E}$ & Jul. 2000 & $-1.6(3)$ & - \\
\hline 2 & Mamatlar & $3756061 \mathrm{~N} 3055549 \mathrm{E}$ & Jul. 2001 & $-1.4(2)$ & - \\
\hline 2 & Mamatlar & $3756061 \mathrm{~N} 3055549 \mathrm{E}$ & Aug. 2003 & $-2.1(2)$ & $0.7080(2)$ \\
\hline 2 & south of Barla & $3757370 \mathrm{~N} 3046210 \mathrm{E}$ & Aug. 2003 & $-1.9(2)$ & $0.7080(1)$ \\
\hline 3 & Taşevi & $3816027 \mathrm{~N} 3049217 \mathrm{E}$ & Jul. 2001 & $-3.8(1)$ & - \\
\hline 3 & Taşevi & $3816110 \mathrm{~N} 3050270 \mathrm{E}$ & Aug. 2003 & $-4.0(2)$ & $0.7079(1)$ \\
\hline 4 & Bedre, near pumpstation & $3753437 \mathrm{~N} 3048479 \mathrm{E}$ & Jul. 2000 & $-1.1(2)$ & - \\
\hline 5 & East side near Hacilar & $3800199 \mathrm{~N} 3058021 \mathrm{E}$ & Jul. 2000 & $-1.1(1)$ & - \\
\hline \multicolumn{6}{|c|}{ Eber Lake } \\
\hline 6 & Southern part & $3836462 \mathrm{~N} 3107430 \mathrm{E}$ & Jul. 2001 & $-0.2(1)$ & - \\
\hline 6 & Southern part & $3836462 \mathrm{~N} 3107430 \mathrm{E}$ & Jul. 2001 & $-0.8(2)$ & - \\
\hline 6 & Near Doğanköy & $3837430 \mathrm{~N} 3107220 \mathrm{E}$ & Aug. 2003 & $-3.5(1)$ & $0.7101(1)$ \\
\hline 7 & Channel of lake near Doğanköy & $3836444 \mathrm{~N} 3105342 \mathrm{E}$ & Aug. 2005 & - & $0.7149(1)$ \\
\hline \multicolumn{6}{|c|}{ Beyşehir Lake } \\
\hline 8 & North of Gedikli & $3755337 \mathrm{~N} 3118547 \mathrm{E}$ & Jul. 2002 & $-0.2(2)$ & - \\
\hline 9 & Gedikli near kooperativ & $3753280 \mathrm{~N} 3120360 \mathrm{E}$ & Aug. 2003 & $-1.3(2)$ & $0.7085(1)$ \\
\hline 10 & Southwest part & $3736528 \mathrm{~N} 3127194 \mathrm{E}$ & Jul. 2002 & $-1.0(2)$ & - \\
\hline 11 & Kusluca & $3749534 \mathrm{~N} 3133562 \mathrm{E}$ & Jul. 2002 & $-0.5(2)$ & $0.7085(1)$ \\
\hline 11 & Kusluca & $3749540 \mathrm{~N} 3134110 \mathrm{E}$ & Aug. 2003 & $-0.5(2)$ & $0.7085(1)$ \\
\hline \multicolumn{6}{|c|}{ Isıklı Lake } \\
\hline 12 & At Beydilli at shore & $3815418 \mathrm{~N} 2955330 \mathrm{E}$ & Jul. 2001 & $-2.4(1)$ & - \\
\hline 12 & At Beydilli at shore & $3815418 \mathrm{~N} 2955330 \mathrm{E}$ & Aug. 2003 & $-5.2(2)$ & $0.7082(1)$ \\
\hline 12 & At Beydilli off shore & $3815342 \mathrm{~N} 2955276 \mathrm{E}$ & Jul. 2002 & $-6.2(1)$ & - \\
\hline \multicolumn{6}{|c|}{ Gölcük Lake } \\
\hline 13 & South part & $3744016 \mathrm{~N} 3029282 \mathrm{E}$ & Jul. 2001 & $-3.4(1)$ & - \\
\hline \multicolumn{6}{|c|}{ Sakarya river } \\
\hline 14 & Gülçayır & $3914407 \mathrm{~N} 3123577 \mathrm{E}$ & Jul. 2002 & $-9.7(2)$ & - \\
\hline 14 & Gülçayır & $3914407 \mathrm{~N} 3123577 \mathrm{E}$ & Aug. 2003 & $-9.6(2)$ & $0.7080(1)$ \\
\hline 15 & Near Gordion & $3939129 \mathrm{~N} 3158380 \mathrm{E}$ & Jul. 2002 & $-9.1(1)$ & - \\
\hline 16 & Sarıcakaya & $4003425 \mathrm{~N} 3038307 \mathrm{E}$ & Jul. 2002 & $-9.3(1)$ & - \\
\hline 17 & Mekece & $4026345 \mathrm{~N} 3003183 \mathrm{E}$ & Jul. 2002 & $-9.4(3)$ & - \\
\hline \multicolumn{6}{|c|}{ Büyük Menderes basin } \\
\hline 18 & Near Söke & $3742223 \mathrm{~N} 2728507 \mathrm{E}$ & Jul. 2002 & $-6.9(1)$ & - \\
\hline 19 & Near Yenipazar & $3751271 \mathrm{~N} 2811344 \mathrm{E}$ & Jul. 2002 & $-7.1(1)$ & - \\
\hline 20 & Near Saraköy & $3757059 \mathrm{~N} 2855036 \mathrm{E}$ & Jul. 2002 & $-7.7(1)$ & - \\
\hline 21 & North of Citak & $3809250 \mathrm{~N} 2938246 \mathrm{E}$ & Jul. 2001 & $-4.6(2)$ & - \\
\hline 21 & North of Citak & $3809250 \mathrm{~N} 2938246 \mathrm{E}$ & Jul. 2002 & $-6.4(2)$ & - \\
\hline 21 & North of Citak & $3809250 \mathrm{~N} 2938246 \mathrm{E}$ & Aug. 2003 & $-5.3(2)$ & $0.7081(1)$ \\
\hline 22 & Source area near Eumeneia & $3819225 \mathrm{~N} 2951020 \mathrm{E}$ & Jul. 2001 & $-9.2(3)$ & - \\
\hline 22 & Source area near Eumeneia & $3819225 \mathrm{~N} 2951020 \mathrm{E}$ & Aug. 2003 & $-9.1(2)$ & $0.7093(1)$ \\
\hline 23 & Source area at Gökgöl & $3812175 \mathrm{~N} 3002519 \mathrm{E}$ & Jul. 2001 & $-9.3(1)$ & - \\
\hline \multicolumn{6}{|c|}{ Aksu river } \\
\hline 24 & South of Karacaören II & $3713410 \mathrm{~N} 3047570 \mathrm{E}$ & Jul. 2002 & $-5.9(1)$ & - \\
\hline 24 & South of Karacaören II & $3713410 \mathrm{~N} 3047570 \mathrm{E}$ & Aug. 2003 & $-5.9(2)$ & $0.7078(1)$ \\
\hline \multicolumn{6}{|c|}{ Küçük Menderes } \\
\hline 25 & Near Selçuk & $3758367 \mathrm{~N} 2721113 \mathrm{E}$ & Jul. 2002 & $-4.1(1)$ & - \\
\hline \multicolumn{6}{|c|}{ Isparta river } \\
\hline 26 & North of Asağigökdere & $3739353 \mathrm{~N} 3043027 \mathrm{E}$ & Jul. 2002 & $-7.1(1)$ & - \\
\hline \multicolumn{6}{|c|}{ Porsuk River } \\
\hline 27 & Opposite Gordion & $3940388 \mathrm{~N} 3158124 \mathrm{E}$ & Jul. 2002 & $-7.8(1)$ & - \\
\hline 28 & Near Ahmetoğlu & $3933256 \mathrm{~N} 3004236 \mathrm{E}$ & Jul. 2002 & $-8.9(1)$ & - \\
\hline \multicolumn{6}{|c|}{ Gediz river } \\
\hline 29 & North of Manisa & $3838373 \mathrm{~N} 2726324 \mathrm{E}$ & Jul. 2002 & $-6.6(1)$ & - \\
\hline 30 & North of Salihli & $3831075 \mathrm{~N} 2808055 \mathrm{E}$ & Jul. 2002 & $-7.3(1)$ & - \\
\hline 31 & Near Yurtbası & $3836073 \mathrm{~N} 2848557 \mathrm{E}$ & Jul. 2002 & $-7.5(1)$ & - \\
\hline 32 & At Yenikent & $3852096 \mathrm{~N} 2916484 \mathrm{E}$ & Jul. 2002 & $-8.7(2)$ & - \\
\hline
\end{tabular}


and operating in static mode on $\mathrm{CO}_{2}$ after equilibration with the water in an off-line vacuum system at $25^{\circ} \mathrm{C}$. Forty-five water samples were collected in 2003 and analyzed in the Saskatchewan Isotope Laboratory, University of Saskatchewan (Canada), using a Finnigan TC-EA coupled to a Delta plus $\mathrm{XL}$ instrument operating in continuous flow mode. All $\delta^{18} \mathrm{O}_{\mathrm{w}}$ values are reported in the standard delta notation as per mil deviations relative to VSMOW (Vienna Standard Mean Ocean Water). The external reproducibility $(1 \sigma)$ was determined by replicate analyses of internal standards and is $\pm 0.1 \%$ and $0.3 \%$ for the $\mathrm{CO}_{2}$-equilibration and carbon reduction methods, respectively.

${ }^{86} \mathrm{Sr} /{ }^{87} \mathrm{Sr}$ ratios of 12 water samples were measured in the Saskatchewan Isotope Laboratory by thermal ionization mass spectrometry (TIMS) (Table 1). Strontium was purified from matrix ions using cation exchange resin, and the purified $\mathrm{Sr}$ was loaded onto single tantalum filaments with phosphoric acid and Ta-oxide powder. The measurements were performed using a Finnigan Triton instrument in static multi-collection mode. Instrumental mass fractionation was corrected using an exponential law to a ${ }^{86} \mathrm{Sr} /{ }^{88} \mathrm{Sr}$ ratio of 0.1194 . External precision of the ${ }^{87} \mathrm{Sr} /{ }^{86} \mathrm{Sr}$ measurements performed during the course of this work was $\pm 20 \mathrm{ppm}(2 \sigma)$ (waters and fish teeth) based on repeated measurements of SRM 987, which yielded $0.710260 \pm 13$.

\subsection{Selection of fish material and isolation of enamel}

Forty modern fish were obtained from lakes in the Anatolian region in the summers of 1996, 1997, 2001 and 2003 (Table 2). This material includes specimens of domestic carp from commercial fishing in Lakes Beyşehir, Eber and Eğirdir, as well as a wild carp from the Karabalut River that empties into Akşehir Lake. In addition to these localities that are believed to belong to the natural distribution area of the species, we also included carp from Gölcük Lake, where former presence is doubtful. Gölcük Lake, however, is a stagnant water body closest to Sagalassos that could, in theory, provide a suitable habitat for carp, but for which the species was not reported during the earliest survey published (Kosswig and Sözer, 1945). Domestic carp is also found today in Iş1klı Lake, an artificial lake in the upper reaches of the Büyük Menderes basin, but the species was not found when sampling this locality, and instead we analyzed a specimen of tench (Tinca tinca). A crucian carp (Carassius carassius gibelio) collected along the shores of Eber Lake was analysed to check the intra-site variability.

Archaeological specimens were chosen from abundant well-preserved material of the Early Byzantine period (450-650 AD) of Sagalassos (Table 2). Specimens are from different occupation and destruction layers within the same house in the Domestic Quarter where kitchen and table refuse is abundant (Putzeys et al., in press). We selected both non-erupted carp teeth and erupted teeth some of which remained positioned into the pharyngeal plate. For one specimen, bone from the pharyngeal plate was also collected (Table 3) for comparison of diagenetic alteration of bone and enamel. Additionally, we selected a cicek ( $P$. handlirschii) pharyngeal plate.

Carp have well-developed heterodont dentition on the modified fifth branchial arches. Pharyngeal teeth are adapted for triturating food and as for all Cyprinids are replaced continuously throughout life (Evans and Deubler, 1955; Harder, 1975; Sibbing, 1982). They are composed of dentine capped with enamel. All specimens were mechanically cleaned under a microscope and sonicated in deionized water to remove sediment contamination. Enamel caps were separated from the dentine using a dental drill. Depending on the individual carp tooth sizes, we performed $\mathrm{O}$ and $\mathrm{Sr}$ isotope analyses on one tooth, or a combination of different teeth from a single pharyngeal plate. When we analyzed a single tooth per individual, the sample powder was split into two sub-samples. Teeth of tench, crucian carp and cicek are small and several teeth of the same individual were mixed together. For tench and cicek enamel and dentine were mixed.

\subsection{Isolation of phosphate oxygen from fish teeth for $\delta^{18} \mathrm{O}$ analysis}

The method used for preparation of samples for phosphate oxygen isotope analysis was modified after Crowson et al. (1991). In order to remove any organic matter, samples were soaked in $1 \mathrm{ml}$ of a solution of sodium hypochlorite $(\mathrm{NaOCl})$ for $24 \mathrm{~h}$, and then rinsed at least eight times in deionized water. Between 1.8 and $6.3 \mathrm{mg}$ of pretreated enamel powder was dissolved in $1 \mathrm{ml}$ of $2 \mathrm{M} \mathrm{HF}$ for $24 \mathrm{~h}$. After centrifugation, the supernatant was collected and the residue rinsed three times with deionized water. The resulting solution was neutralized by adding $1 \mathrm{ml}$ of $2 \mathrm{M} \mathrm{KOH}$ and was then passed through an anion exchange column. $\mathrm{PO}_{4}^{3-}$ ions retained on the column were eluted using $10 \mathrm{ml}$ of $0.5 \mathrm{M} \mathrm{NH}_{4} \mathrm{NO}_{3}$. Concentrated $\mathrm{NH}_{4}^{+}$and $2 \mathrm{M} \mathrm{AgNO}_{3}$ were added to precipitate $\mathrm{PO}_{4}^{3-}$ ions as $\mathrm{Ag}_{3} \mathrm{PO}_{4}$ crystals in a waterbath at $70^{\circ} \mathrm{C}$ overnight. Extraction yields, defined as the ratios between the amount of $\mathrm{Ag}_{3} \mathrm{PO}_{4}$ crystals obtained and the total amount possible, ranged from $56 \%$ for smaller samples to $100 \% . \mathrm{Ag}_{3} \mathrm{PO}_{4}$ was loaded into silver capsules and the phosphate oxygen was converted to $\mathrm{CO}$ in a high temperature $\left(1450{ }^{\circ} \mathrm{C}\right.$ ) furnace (Finnigan TC-EA). CO gas was purified through a GC column and introduced into the electron impact ion source of a Finnigan Delta plus XL instrument for mass spectrometric determination of oxygen isotope abundances. The data are reported in the standard delta notation as per mil deviations relative to the VSMOW (Vienna Standard Mean Ocean Water) standard. Accuracy and precision were monitored through replicate analyses of two internal laboratory standards Florida phosphorite NBS120c $\delta^{18} \mathrm{O} \quad\left(\mathrm{PO}_{4}^{3-}\right)=$ $22.23 \pm 0.18 \%(n=5)$ and Aldrich ${ }^{\mathrm{TM}}$ hydroxylapatite $\delta^{18} \mathrm{O}$ $\left(\mathrm{PO}_{4}^{3-}\right)=14.14 \pm 0.33 \%$ oo $(n=6)$.

\subsection{Isolation of $\mathrm{Sr}$ from fish material for determination of ${ }^{87} \mathrm{Sr} /{ }^{86} \mathrm{Sr}$ and $\mathrm{Sr} / \mathrm{Ca}$ ratios}

Aliquots of enamel powder from modern specimens were dissolved in $2.0 \mathrm{~N} \mathrm{HNO}_{3}$, dried down and converted to 
Table 2

${ }^{87} \mathrm{Sr} /{ }^{86} \mathrm{Sr}$ ratios of modern fish (Anatolia) and archaeological fish from the site of Sagalassos

\begin{tabular}{|c|c|c|c|c|c|c|}
\hline \multirow[t]{2}{*}{ Origin } & \multirow[t]{2}{*}{ Species } & \multirow[t]{2}{*}{ Collection } & \multirow[t]{2}{*}{$\delta^{18} \mathrm{O}$ VSMOW } & \multirow[t]{2}{*}{ No leaching } & \multicolumn{2}{|l|}{${ }^{86} \mathrm{Sr} /{ }^{87} \mathrm{Sr}$} \\
\hline & & & & & Residue after 7 leaches & 7th leachate \\
\hline \multicolumn{7}{|l|}{ Ĕgirdir Lake } \\
\hline Akkeçili & C. carpio & 23 Aug. 1997 & - & $0.7080(1)$ & - & - \\
\hline Bagoren köyü & C. carpio & 22 July 1997 & - & $0.7080(1)$ & - & - \\
\hline Bagoren köyü & C. carpio & 22 July 1997 & - & $0.7080(1)$ & - & - \\
\hline East side & C. carpio & 16 May 1997 & - & $0.7079(1)$ & - & \\
\hline \multirow[t]{3}{*}{ Eber Lake } & C. carpio & 9 Aug. 2003 & - & $0.7093(1)$ & - & - \\
\hline & C. carpio & 9 Aug. 2003 & - & $0.7089(1)$ & - & - \\
\hline & C. carassius & 9 Aug. 2003 & - & $0.7092(1)$ & - & - \\
\hline \multicolumn{7}{|l|}{ Beyşehir Lake } \\
\hline \multirow[t]{2}{*}{ Beyşehir market } & C. carpio & 5 Aug. 1996 & - & $0.7091(2)$ & - & - \\
\hline & & & - & $0.7090(1)$ & - & - \\
\hline Kanlıboğaz & C. carpio & 14 May 1997 & - & $0.7085(1)$ & - & - \\
\hline Gedikli & C. carpio & & - & 0.7088 & - & - \\
\hline Gedikli & C. carpio & 7 Aug. 2003 & - & 0.7087 (1) & - & - \\
\hline Kusluca & C. carpio & 7 Aug. 2003 & - & 0.7085 (1) & - & - \\
\hline Isıklı Lake & T. tinca & 19 July 2001 & - & $0.7080(1)$ & - & - \\
\hline Gölcük Lake & C. carpio & 1 Aug. 1996 & - & 0.7038 (1) & - & - \\
\hline Karabalut river & C. carpio & 12 May 1996 & - & 0.7099 (1) & - & - \\
\hline \multicolumn{7}{|l|}{ Sagalassos } \\
\hline DA-1 & C. carpio & - & 22.4 & - & 0.7068 & $0.7068(2)$ \\
\hline DA-3 & C. carpio & - & 18.1 & - & $0.7071(1)$ & - \\
\hline DA-4 & C. carpio & - & - & - & 0.7075 & - \\
\hline DA-5 & C. carpio & - & 21.3 & - & 0.7062 (1) & $0.7063(2)$ \\
\hline DA-6 & C. carpio & - & 20.0 & - & 0.7075 (1) & - \\
\hline DA-7 & C. carpio & - & 18.7 & - & - & \\
\hline DA-8 & C. carpio & - & 19.5 & - & 0.7060 & - \\
\hline DA-9 & C. carpio & - & 19.6 & - & - & \\
\hline DA-11 & C. carpio & - & 19.6 & - & $0.7072(1)$ & - \\
\hline DA-12 & C. carpio & - & 19.3 & - & $0.7076(1)$ & - \\
\hline DA-13 & C. carpio & - & 18.0 & - & $0.7090(1)$ & - \\
\hline DA-14 & C. carpio & - & 18.0 & - & - & \\
\hline DA-15 & C. carpio & - & 20.3 & - & $0.7074(1)$ & - \\
\hline DA-16 & C. carpio & - & 19.2 & - & $0.7075(1)$ & - \\
\hline DA-17 & C. carpio & - & 19.2 & - & $0.7075(1)$ & - \\
\hline DA-18 & C. carpio & - & 20.2 & - & - & \\
\hline DA-19 & C. carpio & - & 19.5 & - & 0.7071 & - \\
\hline DA-20 & C. carpio & - & 19.3 & - & $0.7075(1)$ & - \\
\hline DAP-01 & P. handlirschii & - & 19.7 & - & - & - \\
\hline
\end{tabular}

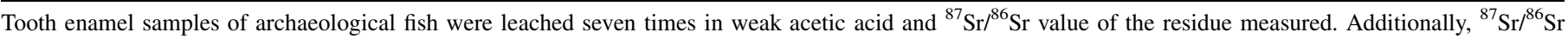
value of the 7 th leachate was measured for two individuals.

chloride form. The $\mathrm{Sr}$ was purified from matrix elements and ${ }^{87} \mathrm{Sr} /{ }^{86} \mathrm{Sr}$ ratios determined following the same procedures outlined above for dissolved $\mathrm{Sr}$ in natural waters.

High precision measurements of $\mathrm{Sr} / \mathrm{Ca}$ ratios were determined by isotope dilution thermal ionization mass spectrometry (ID-TIMS) using a ${ }^{48} \mathrm{Ca}-{ }^{42} \mathrm{Ca}-{ }^{84} \mathrm{Sr}$ triple spike in the Saskatchewan Isotope Laboratory. Strontium and calcium were purified from matrix elements using cation exchange chromatography. Preparation and calibration of the triple spike and mass spectrometry is described in Holmden and Hudson (2003). Replicate analysis of a gravimetrically prepared $\mathrm{Sr} / \mathrm{Ca}$ standard yielded a reproducibility of $\pm 0.1 \%$ $(2 \sigma)$ on the ratio. All $\mathrm{Sr} / \mathrm{Ca}$ ratios are reported in units of millimoles/mole.

\subsection{Sr leaching technique utilizing $\mathrm{Sr} / \mathrm{Ca}$ as a progress indicator}

To calibrate the Sr leaching technique, about $10 \mathrm{mg}$ of carp enamel was milled from one modern (Beyşehir Lake) and one archaeological Sagalassos specimen. The powdered enamel was subjected to sequential treatments of $0.1 \mathrm{~N}$ ultrapure acetic acid (Hoppe et al., 2003) from eight to 12 times using a ratio of $\sim 0.5 \mathrm{ml}$ of acid to $10 \mathrm{mg}$ of sample powder. The reaction time for each leaching step was $10 \mathrm{~min}$. Leachate was then decanted after centrifugation and the residue rinsed once with $1 \mathrm{ml}$ of deionized water that was added to the leachate. The residues that remained after leaching were dissolved in $0.2 \mathrm{~N}$ nitric acid. We chose to apply a series of shorter 
Table 3

${ }^{87} \mathrm{Sr} /{ }^{86} \mathrm{Sr}$ ratios and $\mathrm{Sr} / \mathrm{Ca}$ ratios $(\mathrm{mmol} / \mathrm{mol})$ of enamel tooth in sequential acetic acid leaches for a modern carp (Cyprinus carpio) from Beyşehir Lake and an archaeological carp from Sagalassos (Turkey)

\begin{tabular}{|c|c|c|}
\hline Leach number & $\mathrm{Sr} / \mathrm{Ca}$ (millimoles/mole) & ${ }^{87} \mathrm{Sr} /{ }^{86} \mathrm{Sr}$ \\
\hline \multicolumn{3}{|c|}{ Modern tooth enamel C5 (Beyşehir Lake) } \\
\hline 1 & 1.264 & $0.7086(1)$ \\
\hline 2 & 1.102 & - \\
\hline 3 & 1.000 & $0.7086(1)$ \\
\hline 4 & 0.999 & - \\
\hline 5 & 0.987 & $0.7086(1)$ \\
\hline 6 & 0.969 & $0.7086(1)$ \\
\hline 7 & 1.001 & - \\
\hline 8 & 0.975 & - \\
\hline 9 & 1.037 & - \\
\hline 10 & 0.958 & - \\
\hline Residue & 0.991 & $0.7085(1)$ \\
\hline \multicolumn{3}{|c|}{ Fossil tooth DA-17 (Sagalassos) enamel } \\
\hline 1 & 1.329 & $0.7066(1)$ \\
\hline 2 & 1.178 & $0.7068(1)$ \\
\hline 3 & 0.959 & $0.7072(1)$ \\
\hline 4 & 0.928 & $0.7074(2)$ \\
\hline 5 & 0.846 & $0.7075(3)$ \\
\hline 6 & 0.843 & - \\
\hline 7 & 0.848 & - \\
\hline 8 & 0.821 & \\
\hline 9 & 0.845 & \\
\hline \multirow[t]{2}{*}{10} & 0.875 & 0.7075 (1) leach \\
\hline & & $8-12+$ residue \\
\hline 11 & 0.835 & \\
\hline 12 & 0.810 & \\
\hline Residue & 0.841 & \\
\hline Bone & 1.803 & 0.7048 \\
\hline
\end{tabular}

sequential leaches in weak acid rather than a longer leach in stronger acid in order to monitor leach progress using $\mathrm{Sr} / \mathrm{Ca}$ ratios and avoid potential readsorption or exchange of $\mathrm{Sr}$ between leachate and residue. We assumed that the diffusion profile was removed when the $\mathrm{Sr} / \mathrm{Ca}$ ratio between sequential leaches no longer changed. In some cases, the latter leachates and the final residues were pooled in order to obtain enough $\mathrm{Sr}$ for precise measurements of ${ }^{87} \mathrm{Sr} /{ }^{86} \mathrm{Sr}$.

\section{Results and discussion}

\subsection{Variation in $\delta^{18} O_{w}$ values of modern river and lake environments}

Lakes in the Anatolian region have higher $\delta^{18} \mathrm{O}_{\mathrm{w}}$ values than rivers (Fig. 2a). The range of $\delta^{18} \mathrm{O}_{\mathrm{w}}$ values is $-6.2 \%$ to $+3.2 \%$ for the lakes, and $-9.7 \%$ to $-4.1 \%$ for the rivers. The mean difference between lake and river $\delta^{18} \mathrm{O}_{\mathrm{w}}$ values is about $6 \%$ o (Table 1; Fig. 2a). Sakarya River, Porsuk River, Gediz River, Büyük Menderes and Isparta River are clearly discriminated from lakes by $\delta^{18} \mathrm{O}_{\mathrm{w}}$ values (Fig. 2a). Multiple analyses of samples collected from the same site show a relatively large inter-annual variation in $\delta^{18} \mathrm{O}_{\mathrm{w}}$ values, with the exception of the Sakarya River sampling site (Fig. 2a). This variability is not linked to the year of collection but rather to the site of collection within one lake such as in Eğirdir
Lake or within the Büyük Menderes River basin. In general, the lowest values within lakes are from the northern parts, where most river inputs are located (Fig. 2a). These low values in the northern part of lakes, such as at Taşevi in Eğirdir Lake (Fig. 2a) can be related to the influence of river waters that more closely reflect the $\delta^{18} \mathrm{O}_{\mathrm{w}}$ value of local precipitation. Işlklı Lake yielded the lowest $\delta^{18} \mathrm{O}_{\mathrm{w}}$ value values of all the lakes. This lake is an artificially dammed lake within the Büyük Menderes basin and its $\delta^{18} \mathrm{O}_{\mathrm{w}}$ value compares to that of basin rivers.

\section{2. $\delta^{18} O_{p}$ values of Sagalassos fish remains}

$\delta^{18} \mathrm{O}_{\mathrm{p}}$ values of carp from Sagalassos range from +17.5 to $+21.9 \%$, whereas the $\delta^{18} \mathrm{O}_{\mathrm{p}}$ value for the cicek is $+19.2 \%$ (Table 2). In order to determine carp origin, we calculate theoretical $\delta^{18} \mathrm{O}_{\mathrm{w}}$ values experienced by fish (Fig. 2b). We used the oxygen-temperature equation of Longinelli and Nuti (1973) who documented the relationship between the $\delta^{18} \mathrm{O}_{\mathrm{p}}$ value of fish tooth enamel and ambient temperature and $\delta^{18} \mathrm{O}_{\mathrm{w}}$ value. We also assume a potential temperature range experienced by carp during tooth growth. Carp teeth are being replaced continuously throughout life and many times each year, but not all teeth are replaced at the same time or with the same frequency (Harder, 1975). Teeth present in a pharyngeal plate may have erupted in different seasons with the possible exception of the winter when carp metabolism is lowest (Geyer, 1937). Therefore, although carp are able to tolerate a wide range of temperatures (from $3{ }^{\circ} \mathrm{C}$ to $35^{\circ} \mathrm{C}$ : http:// www.fishbase.org) we use a range of paleotemperatures from $10{ }^{\circ} \mathrm{C}$ to $30^{\circ} \mathrm{C}$ to calculate $\delta^{18} \mathrm{O}_{\mathrm{w}}$ values. Using this temperature range, potential $\delta^{18} \mathrm{O}_{\mathrm{w}}$ values inferred from the archaeological teeth range from $-6.1 \%$ to $+3.0 \%$ (Fig. $2 \mathrm{~b}$ ), which is in the range of modern Anatolian lakes (Fig. 2a). Because this range is too high for most rivers (Fig. 2a), the Sakarya, Gediz, Porsuk, Büyük Menderes and Isparta rivers are excluded as potential sources of the Sagalassos fish. There is a minor overlap in $\delta^{18} \mathrm{O}_{\mathrm{w}}$ data between riverine and lacustrine habitats resulting from relatively low values in lake areas near riverine inputs (Fig. 2a). Thus, even though a riverine origin cannot be entirely excluded, it is unlikely. A lacustrine exploitation of the species in antiquity is consistent with modern carp fishing activities that are practised in lakes and closed basins, rather than rivers. Finally, because of the high range of temperature tolerated by carp, calculated $\delta^{18} \mathrm{O}_{\mathrm{w}}$ values among lakes do not enable us to resolve individual lake provenances (Fig. 2b).

\section{3. ${ }^{87} \mathrm{Sr} /{ }^{86} \mathrm{Sr}$ ratios of Anatolian lakes, rivers and modern carp enamel}

The range of ${ }^{87} \mathrm{Sr} /{ }^{86} \mathrm{Sr}$ ratios for dissolved strontium in lakes and rivers of the Anatolian region and in some cases carp tooth enamel from fish caught in regional lakes is 0.7038-0.7101 (Tables 1, 2 and Fig. 3). Most of the lakes cluster between 0.7080 and 0.7090 and are consistent with $\mathrm{Sr}$ weathered from Mesozoic and Cenozoic marine limestones. 


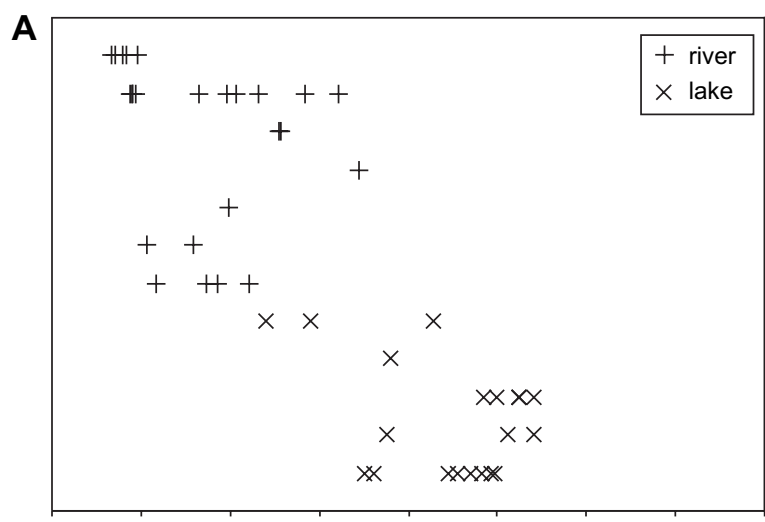

Sakarya river

Büyük Menderes basin

Aksu river

Küçük Menderes

Porsuk river

Gediz river

Isparta river

Isıklı Lake

Gölcük Lake

Beyşehir Lake

Eber Lake

Eğirdir Lake

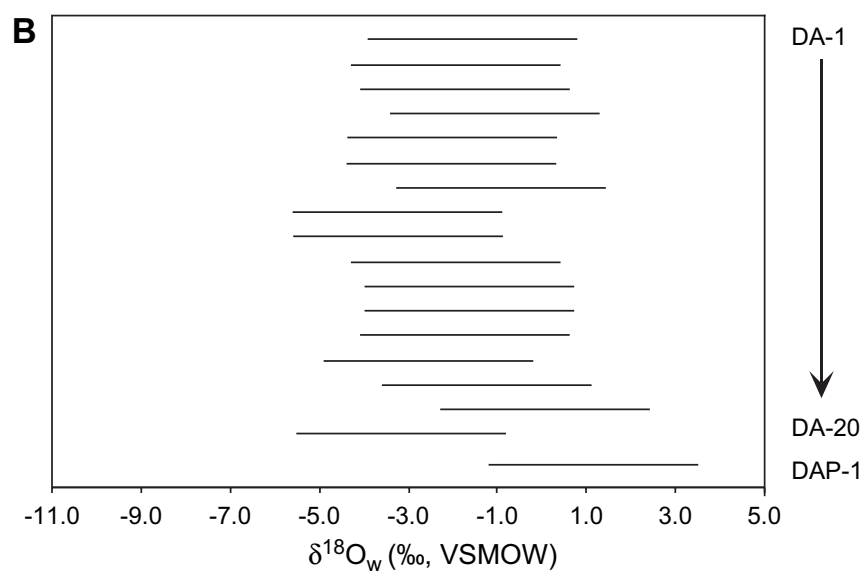

Fig. 2. (A) Variations in $\delta^{18} \mathrm{O}$ values $\left(\delta^{18} \mathrm{O}_{\mathrm{w}}\right.$, \% VSMOW) of modern aquatic environments of Anatolia (Turkey) and (B) reconstruction of potential $\delta^{18} \mathrm{O}$ values of aquatic environments $\left(\delta^{18} \mathrm{O}_{\mathrm{w}}, \%\right.$ VSMOW) inhabited by carp (Cyprinus carpio) and a cicek (Pseudophoxinus handlirschii) collected at the site of Sagalassos. Reconstructed $\delta^{18} \mathrm{O}_{\mathrm{w}}$ values are calculated using $\delta^{18} \mathrm{O}$ values of tooth enamel $\left(\delta^{18} \mathrm{O}_{\mathrm{p}}, \%\right.$ VSMOW), the temperature range tolerated by carps (from $10{ }^{\circ} \mathrm{C}$ to $35^{\circ} \mathrm{C}$ ) and the oxygen-temperature fractionation equation of Longinelli and Nuti (1973). $\times$, lakes; + , rivers.

The ${ }^{87} \mathrm{Sr} /{ }^{86} \mathrm{Sr}$ ratio of dissolved $\mathrm{Sr}$ in the water of Gölcük Lake was not determined but a value of 0.7038 was obtained on tooth enamel from a fish collected from this lake. This low ratio is consistent with the placement of the lake on young volcanic bedrock. Water bodies with the most distinctive ${ }^{87} \mathrm{Sr} /{ }^{86} \mathrm{Sr}$ signatures are more likely to be found in the smaller watersheds, where the lake $\mathrm{Sr}$ budgets are more significantly influenced by weathered $\mathrm{Sr}$ sourced from local lithologies that may be less representative of the region as a whole. For example, the artificial canal of Eber Lake has the highest ${ }^{87} \mathrm{Sr} /{ }^{86} \mathrm{Sr}$ ratio at 0.7149 . The presence of metamorphic Palaeozoic clastic rocks (shales to breccias) near the canal might explain the high ${ }^{87} \mathrm{Sr} /{ }^{86} \mathrm{Sr}$ ratios value $(>0.710)$. The uniform ${ }^{87} \mathrm{Sr} /{ }^{86} \mathrm{Sr}$ ratios in lakes sampled at more than one location indicates that these lakes are well mixed and that isotopically distinct riverine and groundwater inputs are effectively homogenized.

The ${ }^{87} \mathrm{Sr} /{ }^{86} \mathrm{Sr}$ ratios of tooth enamel in fish caught in the lakes are similar, but not identical in most cases to the ${ }^{87} \mathrm{Sr} /{ }^{86} \mathrm{Sr}$ ratios of the corresponding lake waters (Tables 1,2 and Fig. 3). The smallest differences between fish and lakes were found in Lakes Eğirdir and Beyşehir, whereas and largest difference was found in Eber Lake. Generally, fish display a larger variance in ${ }^{87} \mathrm{Sr} /{ }^{86} \mathrm{Sr}$ ratios than their lake water habitats.

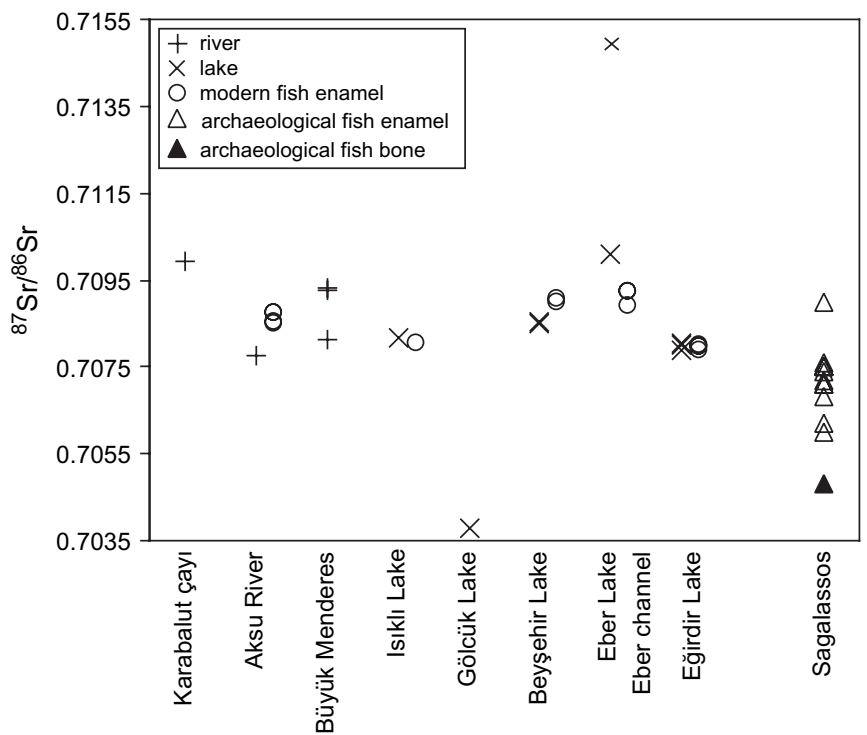

Fig. $3 .{ }^{87} \mathrm{Sr} /{ }^{86} \mathrm{Sr}$ ratios of water environments, tooth enamel of modern fish (Cyprinus carpio and other fish species), tooth enamel, and bone of archaeological carp from Anatolia (Turkey). ${ }^{87} \mathrm{Sr} /{ }^{86} \mathrm{Sr}$ ratios of archaeological samples from Sagalassos are derived from enamel powder residues leached seven times in weak acetic acid. $\times$, lakes; + , rivers; $\bigcirc$, modern teeth; $\Delta$, archaeological teeth; $\boldsymbol{\Delta}$, archaeological bone. 


\subsection{Sr/Ca and ${ }^{87} \mathrm{Sr} /{ }^{86} \mathrm{Sr}$ profiles from sequential leaches of modern and archaeological tooth enamel}

$\mathrm{Sr} / \mathrm{Ca}$ ratios of sequential leaches of powdered enamel prepared from both modern and archaeological specimens of carp teeth are shown in Fig. 4. Both profiles exhibit initially high $\mathrm{Sr} / \mathrm{Ca}$ ratios, decreasing rapidly in the first four leaches, and levelling off in the remaining nine leaches with very little change in $\mathrm{Sr} / \mathrm{Ca}$. The rapid early decline in $\mathrm{Sr} / \mathrm{Ca}$ ratios apparent in the first four leaches is interpreted to reflect the removal of the $\mathrm{Sr}$ diffusion profile that was acquired by the tooth enamel in vivo and/or post-mortem (Table 3; Fig. 4). The plateau region of the curve is interpreted as the Sr-reservoir within the tooth enamel that most closely reflects the $\mathrm{Sr} / \mathrm{Ca}$ ratio of the tooth when it first erupted from the jawbone of the host organism and, therefore, the Sr domain within the tooth that is the most likely to record a primary environmental signature.

The increase in Sr content of the surface layers of modern carp enamel is consistent with observations of human tooth enamel (Little and Barrett, 1976). It occurs after the tooth has erupted, and is caused by the diffusion of $\mathrm{Sr}$ into teeth from diet and ingested water. Because the formation of apatite discriminates against $\mathrm{Sr}$ in favor of $\mathrm{Ca}$, newly erupted fish teeth will have a lower $\mathrm{Sr} / \mathrm{Ca}$ ratio than the lake water. The fact that the erupted tooth is continuously bathed in lake water while resident in the jawbone of the fish means that the surface of the tooth enamel will adsorb Sr. Additional $\mathrm{Sr}$ gains from mastication of food is also likely. As a consequence, in the lake, the in vivo development of the diffusion profile serves to re-enforce the lake water ${ }^{87} \mathrm{Sr} /{ }^{86} \mathrm{Sr}$ signature in the tooth. As expected, the ${ }^{87} \mathrm{Sr} /{ }^{86} \mathrm{Sr}$ ratios for leaches performed on the modern specimen 2003-C5 are uniform across the entire leach spectrum, independent of $\mathrm{Sr} / \mathrm{Ca}$ ratio (Fig. 5).

As expected, a trend of decreasing $\mathrm{Sr} / \mathrm{Ca}$ ratios was also found during the first four leachates of the archaeological tooth (DA-17) (Fig. 4). In this case, however, there is a strong negative correlation between declining $\mathrm{Sr} / \mathrm{Ca}$ ratio and increasing ${ }^{87} \mathrm{Sr} /{ }^{86} \mathrm{Sr}\left(R^{2}=0.99\right)$ (Fig. 5). This linear relationship is interpreted as a two-component mixing line that reflects leaching of enamel grains containing wholly biogenic (lake-

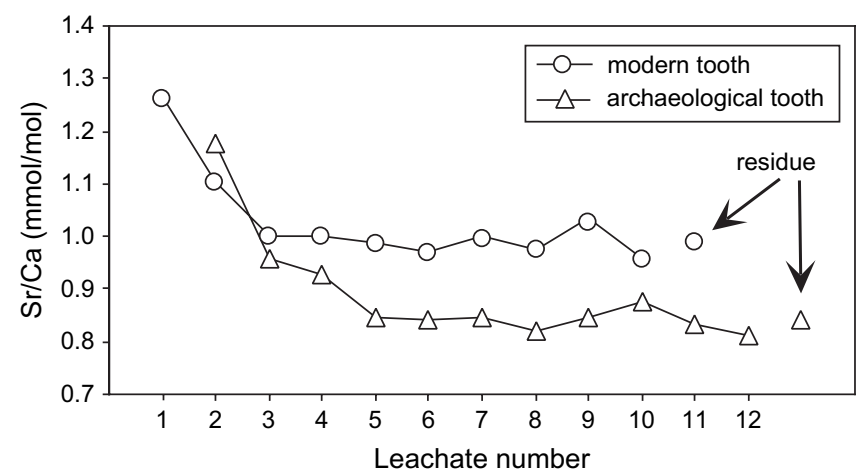

Fig. 4. Sr/Ca concentration $(\mathrm{mmol} / \mathrm{mol})$ of the sequential leachates and residues of a carp modern enamel $(\bigcirc)$ and an archaeological tooth enamel $(\triangle)$ after treatment in weak acetic acid.

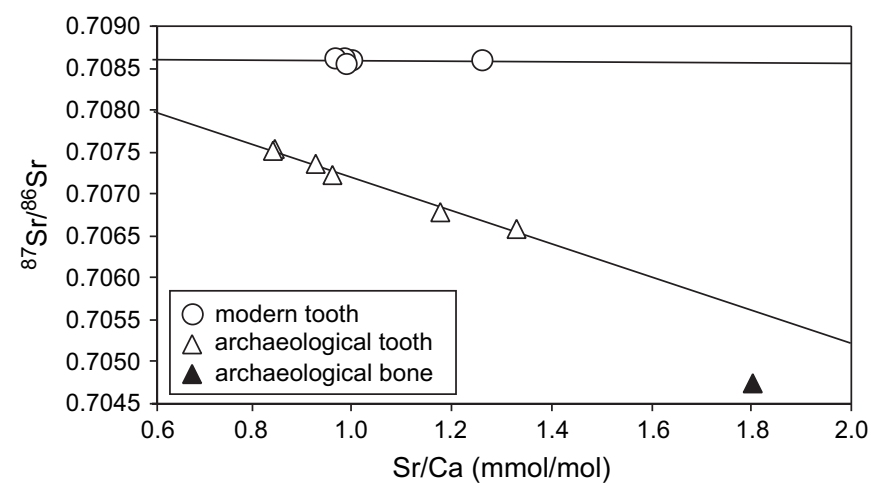

Fig. 5. Comparison of ${ }^{87} \mathrm{Sr} /{ }^{86} \mathrm{Sr}$ ratios and $\mathrm{Sr} / \mathrm{Ca}$ ratios $(\mathrm{mmol} / \mathrm{mol})$ of tooth enamel in sequential acetic acid leaches for a modern carp (Cyprinus carpio) from Beysehir Lake $(\bigcirc)$, and tooth enamel $(\Delta)$ and bone $(\boldsymbol{\Delta})$ of an archaeological carp from Sagalassos (Turkey).

derived) $\mathrm{Sr}$, that is relatively uniform in both ${ }^{87} \mathrm{Sr} /{ }^{86} \mathrm{Sr}$ $(\sim 0.7075)$ and $\mathrm{Ca} / \mathrm{Sr}$ ratio, and enamel grains containing various amounts of a diagenetic $\mathrm{Sr}$ overprint characterized by lower ${ }^{87} \mathrm{Sr} /{ }^{86} \mathrm{Sr}$ and higher $\mathrm{Sr} / \mathrm{Ca}$ ratios (Fig. 5). The excellent fit also means that $\mathrm{Sr}$ from the diagenetic reservoir drawn into the tooth while resident in the midden is also very homogenous in terms of its ${ }^{87} \mathrm{Sr} /{ }^{86} \mathrm{Sr}$ and $\mathrm{Sr} / \mathrm{Ca}$ ratio. To estimate the ${ }^{87} \mathrm{Sr} /{ }^{86} \mathrm{Sr}$ and $\mathrm{Sr} / \mathrm{Ca}$ ratios of the diagenetic reservoir, we analyzed the pharyngeal bone from the DA-17 specimen because original bone ${ }^{87} \mathrm{Sr} /{ }^{86} \mathrm{Sr}$ ratios are more susceptible to being completely diagenetically overprinted (Table 3; Fig. 5). Despite the fact that the bone was resident in the midden for the same amount of time as the tooth, and was indeed adjacent to the tooth in the same soil microenvironment, the bone yielded a ${ }^{87} \mathrm{Sr} /{ }^{86} \mathrm{Sr}$ ratio of 0.7048 , and a relatively high $\mathrm{Sr} /$ Ca ratio (Fig. 5). The low ${ }^{87} \mathrm{Sr} /{ }^{86} \mathrm{Sr}$ ratio of the diagenetic $\mathrm{Sr}$ indicates that the soils of the midden are derived from the weathering of a young basaltic parent rock. Indeed, Sagalassos is situated on the contact between an ophiolitic sheet (basaltic paleo-ocean crust) and a limestone sheet, and subsoil there is indeed formed by weathered ophiolitic material around limestone klippes and slumps.

The $\mathrm{Sr} / \mathrm{Ca}$ profile derived from DA-17 was used to calibrate the extent of sequential leaching necessary to remove the Srdiffusion profile in the other specimens of archaeological tooth found in the same midden. In order to ensure that all of the post-mortem Sr-addition is removed, the protocol we adopted for the remaining archaeological specimens was to apply seven sequential leaches instead of four and to determine the ${ }^{87} \mathrm{Sr} /{ }^{86} \mathrm{Sr}$ ratio on the enamel residue that remains after the 7 th leach. In order to evaluate the effectiveness of our method, we analyzed both the 7th leach and residue for two individuals. The ${ }^{87} \mathrm{Sr} /{ }^{86} \mathrm{Sr}$ ratio for the 7 th leach is identical to the residue (within the error of the analysis) for specimen DA-1 and nearly identical to the residue (the difference lies just outside of analytical error) for DA-5 (Table 2). Therefore, the plateau region of the $\mathrm{Sr} / \mathrm{Ca}$ 'leach progress' curve was obtained for these two individuals and the ${ }^{87} \mathrm{Sr} /{ }^{86} \mathrm{Sr}$ ratio of the residues was considered to reflect the original in vivo signature of the fish tooth. 
4.5. ${ }^{87} \mathrm{Sr} /{ }^{86} \mathrm{Sr}$ ratios in archaeological carp

from the Sagalassos midden

${ }^{87} \mathrm{Sr} /{ }^{86} \mathrm{Sr}$ ratios of carp specimens derived from enamel powder residues leached seven times in weak acetic acid, are shown in Table 2 and Fig. 3. They range from 0.7060 to 0.7090 . The inter-individual variability in ${ }^{87} \mathrm{Sr} /{ }^{86} \mathrm{Sr}$ is higher for the archaeological samples than for modern fish from a single origin (Fig. 3). Three specimens (DA-01, DA-05 and DA08 ) have relatively low values that are characteristic of lakes with basaltic and/or marine carbonate rocks weathering in the watershed of the lake. Most of the other individuals (DA-04, DA-06, DA-11, DA-12, DA-16, DA-17, DA-20) have ${ }^{87} \mathrm{Sr} /{ }^{86} \mathrm{Sr}$ ratios that are consistent with pure limestone weathering in the lake's watershed $(0.7070-0.7075)$. Only one fish (DA-13) appears to have come from a characterized source, which could be Eber Lake or Beyşehir Lake (Tables 1, 2 and Fig. 3). Both lakes are considered a priori as potential origins of carp together with Lakes Eğirdir or Akşehir. The possible Eber Lake provenance of this specimen is compatible with the fact that pike, which is the most common fresh water fish consumed in Sagalassos after carp and cicek, is found in Eber Lake (Geldiay and Balık, 1996). However, the exclusion of Eğirdir Lake as a potential source for Sagalassos carp is somewhat surprising. This lake provided large amounts of cicek, as attested by the numerous remains found at Sagalassos (Putzeys et al., in press) and one would have expected concomitant carp fishing activities. On the contrary, the exclusion of Gölcük Lake as a potential origin is consistent with previous work. Despite its geographical proximity to Sagalassos and the presence of modern carp, it was suggested that the species was recently introduced in Golcük Lake (Geldiay and Balık, 1996; Van Neer et al., 2004). This is in accordance with the absence of carp in Golcük Lake reported in the 1940s by Kosswig and Sözer (1945).

The significant degree of variability in ${ }^{87} \mathrm{Sr} /{ }^{86} \mathrm{Sr}$ ratios at Sagalassos could suggest that fish might originate from several lakes that have not yet been characterized in the reconnaissance survey of existing lakes. In fact, ${ }^{87} \mathrm{Sr} /{ }^{86} \mathrm{Sr}$ ratios of three individuals (DA-03; DA-11 and DA-19) match those of calcite crusts from Lake Burdur $\left({ }^{87} \mathrm{Sr} /{ }^{86} \mathrm{Sr}\right.$ 0.7072; P. Degryse, unpublished data). We did not initially consider Lake Burdur or other lakes of Anatolia (Lakes Yarışlı and Acigöl) as potential origins for carp because the modern salinity of these lakes is too high for carp survival. Today only one endemic species of killifish (Aphanius anatoliae sureyanus), which has a high salinity tolerance, lives in Burdur Lake. However, carp may have been present in these lakes in the past if the salinity was significantly lower. Apart from the dramatic lowering of lake levels due to excessive pumping and water management projects during the last few decades (Anonymous, 1994a,b, 1995), there is no geological and geomorphological evidence for any significant changes over the last 2000 years (Degryse et al., 2003). There is not a single indication that the lake levels of Yarışlı or Burdur, both located within the territory of Sagalassos in Late Roman and Early Byzantine times, were higher in ancient times, as there are Greco-Roman sites around both lakes that are only a few meters above the present lake level. Additionally, historical written sources mention salt exploitation at the margins of Lake Yarışlı and Burdur Lake (Degryse et al., 2005). From the archaeological record it is known that Sagalassos relied on local sources. Arrianos (Anabasis Alexandri I.29) described how Alexander the Great in 333 BC, after taking Sagalassos, "passed into Phrygia by Ascania Lake (present-day Burdur Lake), where salt crystallizes naturally and is used by the inhabitants who thus need no sea salt". In the geological survey of the area, many patches and accumulations of salts were found around Lakes Burdur, Yarışlı and Aci (Degryse et al., 2005). All this evidence suggests that the salinity of the aforementioned lakes was high. The original, postglacial distribution of carp, prior to stocking with the domestic form, does moreover not seem to have included more southern parts of Anatolia (Geldiay and Balık, 1996) and there is hence also a zoogeographical argument to raise serious doubts on the former presence of carp in one of these lakes during the period under consideration.

Therefore, our geochemical results could indicate that the carp originated from outside the region of Anatolia considered in the present study - and this would have important implications for the reconstruction of trade routes used by people during early Byzantine times-or that the carp signature does not indicate fish provenance. Taking into account the abundant archaeological information on former trade relationships provided by the analysis of ceramics, coins, building stones and epigraphy (Devijver and Waelkens, 1997; Poblome, 1999), it is highly unlikely that the carp originated from outside the region of Anatolia that has been considered herein. Unlike the Egyptian fish imports that were sundried or smoked, carp are traditionally not cured and long distance trade of cyprinids in general seems almost non-existent (Van Neer et al., 2004). We suppose that carp was traded in fresh form, also because this species is able to survive for a long time out of the water when it is covered with humid vegetal matter. Hence, the ability of carp geochemical signatures to reflect geographical origin or to preserve the genuine signal has to be questioned in this case.

\subsection{Potential pitfalls using ${ }^{87} \mathrm{Sr} /{ }^{86} \mathrm{Sr}$ ratios in fossil carp teeth as provenance indicator}

One explanation for the inability of $\mathrm{Sr}$ to trace fish origin is that the isotopic signatures of modern habitats are not representative of those in the past. This could result from a change in lake level and a consecutive change in the composition of the bedrock that is weathered. As discussed previously, for most of the lakes it is clear that the lake water levels have not changed significantly in historic times, as sites are located very near to the shores. Moreover, no "new" lithologies would have been weathered to provide a significant input of $\mathrm{Sr}$ and a change in the $\mathrm{Sr}$ signature of the lake in any of these examples.

A second potential limitation relates to the lack of correspondence between fish and environmental water. We observed an imperfect correspondence between some of the modern fish and lake water signals, especially in the case of 
Eber lake (3rd decimal place), also apparent in the case of Beyşehir lake (4th decimal place). One possibility is that dissolved $\mathrm{Sr}$ is not homogenous within the lake especially in places where lacustrine and riverine waters meet. If the fish inhabited the river mouths, then their ${ }^{87} \mathrm{Sr} /{ }^{86} \mathrm{Sr}$ signatures may be different from the main body of the lake. An alternative explanation is that $\mathrm{Sr}$ in fish teeth originates from two sources with different ${ }^{87} \mathrm{Sr} /{ }^{86} \mathrm{Sr}$ ratios. It is estimated that between 25 and $80 \%$ of the in vivo Sr in tooth enamel may be derived from fish diets (Farrell and Campana, 1996; Kennedy et al., 2000; Simkiss, 1974). In many cases the dietary Sr will reflect the ${ }^{87} \mathrm{Sr} /{ }^{86} \mathrm{Sr}$ ratio of dissolved $\mathrm{Sr}$ in the lake. In some cases however, such as in rooted plants or infaunal organisms, some $\mathrm{Sr}$ may be sourced from porewaters in bottom lake sediment that may differ in ${ }^{87} \mathrm{Sr} /{ }^{86} \mathrm{Sr}$ ratio from the overlying lake water due to $\mathrm{Sr}$ released from detritic minerals. Although the congruent weathering of marine limestones appears to dominate the $\mathrm{Sr}$ budgets of the larger lakes under consideration, the lake bottom sediments may reflect greater proportions of clay and mineral particles weathered from volcanic deposits with low ${ }^{87} \mathrm{Sr} /{ }^{86} \mathrm{Sr}$ ratios. Carp can feed on algae adhering to bottom sediment, thus, ingesting sedimentary grains and plants that may differ in ${ }^{87} \mathrm{Sr} /{ }^{86} \mathrm{Sr}$ ratio from the dissolved $\mathrm{Sr}$ in the lake. Consequently, a diet influenced by lake sediment porewater is possible. If the $\mathrm{Sr}$ mass balance in fish tissue is strongly shifted toward dietary $\mathrm{Sr}$ sources, then a shift in the ${ }^{87} \mathrm{Sr} /{ }^{86} \mathrm{Sr}$ signatures of a few dietary components may be enough to shift the ${ }^{87} \mathrm{Sr} /{ }^{86} \mathrm{Sr}$ ratio of fish tooth apatite away from that of the lake. A maximum intra-site variability of 0.001 was measured for modern fish. If the ${ }^{87} \mathrm{Sr} /{ }^{86} \mathrm{Sr}$ ratios of Sagalassos teeth are shifted more positive by 0.001 , then they would match several potential origins considered in this study, including Eğirdir and Beyşehir Lakes. However, in case of a 0.001 decrease, Sagalassos tooth ${ }^{87} \mathrm{Sr} /{ }^{86} \mathrm{Sr}$ ratios would not match any of the considered origins. It clearly appears that potential dietary items of carps should be analyzed in future studies in order to evaluate whether their ${ }^{87} \mathrm{Sr} /{ }^{86} \mathrm{Sr}$ ratios differ from lake water signatures.

\subsection{Integrity of ${ }^{87} \mathrm{Sr}{ }^{86} \mathrm{Sr}$ ratios signal in archaeological carp teeth}

Finally, we also have to consider the possibility that fish origin cannot be traced by ${ }^{87} \mathrm{Sr} /{ }^{86} \mathrm{Sr}$ ratios measured in archaeological tooth samples from Sagalassos because they may not be genuine signals. The source of diagenetic Sr has a very low ${ }^{87} \mathrm{Sr} /{ }^{86} \mathrm{Sr}$ ratio as evidenced by the fish bone value of 0.7048 . The true diagenetic end-member could be even lower, possibly near the value of the modern fish from Gölcuik Lake (0.7038), because of the similarity between the geological bedrock at Sagalassos and that of Gölcük Lake. Because of the very contrasting ${ }^{87} \mathrm{Sr} /{ }^{86} \mathrm{Sr}$ ratios between biogenic and diagenetic endmembers, even a small degree of contamination of the enamel can overprint the original lake provenance signal. Mass balance calculations suggest that we have to consider the presence of $10-20 \%$ of diagenetic $\mathrm{Sr}$ in order to drive most Sagalassos teeth to values in the range $0.7075-0.7070$, which would be consistent with a Eğirdir Lake or Işıklı Lake origin.

The fact that two of the three specimens (DA-1, DA-5; Fig. 5) with the present lowest ${ }^{87} \mathrm{Sr} /{ }^{86} \mathrm{Sr}$ ratios exhibited the same ${ }^{87} \mathrm{Sr} /{ }^{86} \mathrm{Sr}$ ratio for their 7 th leach and residue (Table 2) suggests that the plateau region of the $\mathrm{Sr} / \mathrm{Ca}$ 'leach progress' curve was obtained. However, if the diffusion profile spans the entire thickness of the tooth enamel and post-mortem $\mathrm{Sr}$ has been pervasively incorporated into the bioapatite, no amount of sequential leaching will be able to isolate a purely biogenic component (Nelson et al., 1986; Sillen, 1986; Tuross et al., 1989).

The potential presence of $10-20 \%$ of diagenetic Sr in Sagalassos carp teeth is more than that was calculated by Hoppe et al. (2003) for Holocene and Miocene enamel from marine mammals buried in terrestrial contexts. The authors used the same leaching technique and found that pretreatment appeared to remove nearly all ( $\geq 95 \%)$ diagenetic Sr from tooth enamel. We emphasize however that the thick mammalian enamel may not be a good analogue for fish teeth, whose enamel is thinner. It is also possible that some degree of physical mixing between enamel and dentine may have occurred while sampling the carp teeth. Although teeth were carefully sampled in order to avoid this potentially serious pitfall, the enamel-dentine junction is irregular and difficult to visually locate precisely. A small amount of contamination of dentine within the enamel samples may have been possible, and if some of this dentine persisted through the sequential leaches to become part of the final residue, then the measured ${ }^{87} \mathrm{Sr} /{ }^{86} \mathrm{Sr}$ ratios would be lower than the true biogenic signature. In this study, we did not measure $\mathrm{Sr} / \mathrm{Ca}$ ratios for all specimens, relying instead on a $\mathrm{Sr} / \mathrm{Ca}$ reference profile for one archaeological specimen that then served as a guide for developing the leaching protocol for the other samples. In future work, the $\mathrm{Sr} / \mathrm{Ca}$ leach profiles should be measured for all tooth samples, as the presence of dentine in the final residue would likely be revealed as a deviation in the $\mathrm{Sr} / \mathrm{Ca}$ ratio away from the plateau signature owing to the contrasting $\mathrm{Sr} / \mathrm{Ca}$ ratios between altered dentine and pristine (or nearly pristine) enamel.

\section{Conclusions and perspectives}

We examined for the first time the possibility of using geochemical signatures $\left(\delta^{18} \mathrm{Op},{ }^{87} \mathrm{Sr} /{ }^{86} \mathrm{Sr}\right)$ in fish teeth in order to track the geographical origin of fish found in an archaeological context and reconstruct past trade routes. Using the Anatolian region as a case study, we found a relatively large range in geochemical signals of surface waters, that offers the potential to establish the origin of carp consumed in the city of Sagalassos during the Early Byzantine period (450-650 AD). $\delta^{18} \mathrm{O}_{p}$ values of Sagalassos carp enamel suggest that the fish were caught in lakes rather than rivers. However, we were not able to assign a precise geographical origin to most of the carp because the ${ }^{87} \mathrm{Sr} /{ }^{86} \mathrm{Sr}$ ratios did not match those of the local lakes selected as potential origins because of archaeological and zoogeographical evidence.

The lack of correspondence between lake and fish ${ }^{87} \mathrm{Sr} /{ }^{86} \mathrm{Sr}$ ratios highlights several possible sources of uncertainty related 
to lake hydrology, intra-lake variability in ${ }^{87} \mathrm{Sr} /{ }^{86} \mathrm{Sr}$, modernday influences on lake composition, different contributions of $\mathrm{Sr}$ from food and water to the fish teeth, respectively, and post-mortem preservation of the signal during fossilization. Therefore, future studies should include a complete characterization of lake hydrology and a survey of intra-lake spatial variation in ${ }^{87} \mathrm{Sr} /{ }^{86} \mathrm{Sr}$ for water, sediment and food sources prior to applying the method to archaeological settings. A better understanding of the apportionment of strontium in fish tooth enamel from food and water will also be required. It would likewise be necessary to remain alert for irregularities in $\mathrm{Sr} / \mathrm{Ca}$ profiles for all tooth samples. $\mathrm{Sr} / \mathrm{Ca}$ profile trends might reveal the presence of persistent contamination of dentine or diagenetic Sr overprinting of the entire thickness of the enamel. Additionally, $\mathrm{Sr} / \mathrm{Ca}$ ratios might provide another fingerprint with environmental significance.

Finally, the present study also highlights the suitability of isotope dilution thermal ionization mass spectrometry to the study of archaeological fish tooth fossils. It has the advantage over other analytical techniques of requiring as little as 10$20 \mathrm{ng}$ of $\mathrm{Sr}$ in order to make precise and inherently accurate measurements of the $\mathrm{Sr} / \mathrm{Ca}$ ratio $(0.1 \%)$ and ${ }^{87} \mathrm{Sr} /{ }^{86} \mathrm{Sr}$ ratio $(30 \mathrm{ppm})$. Thus, in spite of the small size of fish tooth, and the fact that the leaching process removes most of the Sr present in the tooth before the in vivo $\mathrm{Sr}$ signature is revealed, the experimental approach adopted in this work is robust. We recommend its application for further development of provenance studies in archaeology based on fish teeth, and for further investigations of the potential pitfalls.

\section{Acknowledgements}

We would like to thank Tim Prokopiuk and Bruce Eglington for technical assistance in the laboratory. We also thank Aude Van Driessche (RBINSc) for preparing the map. The contributions of Wim Van Neer and Patrick Degryse to this paper present research results of the Interuniversity Attraction Poles Programme - Belgian Science Policy.

\section{References}

Anonymous, 1994a. Survey of the Inland and Freshwater Fisheries of Turkey. Report by Cofrepêche, Gersar and BRL.

Anonymous, 1994b. Survey of Inland Waterbodies and Fishfarms Turkey. Final report. Appendix 4. Ecological Study. Report by Cofrepêche-Gersar in association with Yapı Teknik for Ministry of Agriculture and Rural Affairs (Turkey).

Anonymous, 1995. Analysis of the Hydrological Balance of the Lakes in the Isparta Region. Report by BRL Ingénierie for Ministry of Agriculture and Rural Affairs (Turkey) and Ministère de l'Agriculture et de la Pêche.

Arndt, A., Van Neer, W., Hellemans, B., Robben, J., Volckaert, F., Waelkens, M., 2003. Roman trade relationship at Sagalassos (Turkey) elucidated by ancient DNA of fish remains. J. Archaeol. Sci. 30, 1095-1105.

Balasse, M., Ambrose, S.H., Smith, A.B., Price, T.D., 2002. The seasonal mobility model for prehistoric herders in the South-western Cape of South Africa assessed by isotopic analysis of sheep tooth enamel. J. Archaeol. Sci. 29, 917-932.

Benson, L., Cordell, L., Vincent, K., Taylor, H., Stein, J., Farmer, G.L., Futa, K., 2003. Ancient maize from Chacoan great houses: where was it grown? Proc. Natl. Acad. Sci. 100, 13111-13115.
Bentley, R.A., Knipper, C., 2005. Geographical patterns in biologically available strontium, carbon and oxygen isotope signatures in prehistoric SW Germany. Archaeometry 47, 629-644.

Blake, R.E., O’Neil, J.R., Garcia, G.A., 1997. Oxygen isotope systematics of biologically mediated reactions of phosphate: I. Microbial degradation of organophosphorus compounds. Geochim. Cosmochim. Acta 61, 44114422.

Crowson, R.A., Showers, W.J., Wright, E.K., Hoering, T.C., 1991. A method for preparation of phosphate samples for oxygen isotope analysis. Anal. Chem. 163, 2397-2400.

Devijver, H., Waelkens, M., 1997. Roman inscriptions from the fifth campaign at Sagalassos. In: Waelkens, M., Poblome, J. (Eds.), Sagalassos IV. Report on the Survey and Excavation Campaigns of 1994 and 1995. Acta Archaeologica Lovaniensia Monographiae, vol. 9. Leuven University Press, Leuven, pp. 293-314.

Degryse, P., Muchez, Ph., Six, S., Waelkens, M., 2003. Identification of ore extraction and metal working in ancient times: a case study of Sagalassos (SW Turkey). J. Geochem. Explor. 77, 65-80.

Degryse, P., Schneider, J., Poblome, J., Muchez, Ph., Haack, U., Waelkens, M., 2005. Geochemical study of Roman to Byzantine Glass from Sagalassos, Southwest Turkey. J. Archaeol. Sci. 32, 287-299.

Driessens, F.C.M., Verbeeck, R.M.H., 1990. Biominerals. CRC Press, Boca Raton, FL.

Elliott, T.A., Forey, P.L., Williams, C.T., Werdelin, L., 1998. Application of the solubility profiling technique to recent and fossil fish teeth. Bull. Soc. Géol. Fr. 169, 443-451.

Evans, H.D., Deubler Jr., E.E., 1955. Pharyngeal tooth replacement in Semotilus atromaculatus and Clinostomus elongatus, two species of Cyprinid fishes. Copeia 1, 31-41.

Farrell, J., Campana, S.E., 1996. Regulation of calcium and strontium deposition on the otoliths of juvenile tilapia; Oreochromis niloticus. Comp. Biochem. Physiol. 115, 103-109.

Geldiay, R., Balık, S., 1996. Türkiye tatlısu Balıkları. Ege Üniversitesi Basımevı Bornova, Izmir.

Geyer, E., 1937. Der zeitliche Ablauf der Bezahnungen und des Zahnwechsels bei Cyprinus carpio L. unter besonderer Berücksichtigung des einsömmerigen Karpfens. Morph. Jb. 80, 208-354.

Harder, W., 1975. Anatomy of Fishes. Schweizerbart, Stuttgart.

Holmden, C., Creaser, R.A., Muehlenbachs, K., Bergstrom, S.M., Leslie, S.A., 1996. Isotopic and elemental systematics of $\mathrm{Sr}$ and $\mathrm{Nd}$ in $454 \mathrm{Ma}$ biogenic apatites: implications for paleoseawater studies. Earth Planet. Sci. Lett. $142,425-437$.

Holmden, C., Hudson, J.D., 2003. ${ }^{87} \mathrm{Sr} /{ }^{86} \mathrm{Sr}$ and $\mathrm{Sr} / \mathrm{Ca}$ investigation of Jurassic molluscs from Scotland: implications for paleosalinities and the $\mathrm{Sr} / \mathrm{Ca}$ ratio of seawater. Geol. Soc. Am. Bull. 115, 1249-1264.

Hoogewerff, J., Papesch, W., Kralik, M., Berner, M., Vroon, P., Miesbauer, H., Gaber, O., Kunzel, K.-H., Kleinjans, J., 2001. The last domicile of the Iceman from Hauslabjoch: a geochemical approach using $\mathrm{Sr}, \mathrm{C}$ and $\mathrm{O}$ isotopes and trace element signatures. J. Archaeol. Sci. 28, 983-989.

Hoppe, K.A., Koch, P.L., Carlson, R.W., Webb, S.D., 1999. Tracking mammoths and mastodons: reconstruction of migratory behaviour using strontium isotope ratios. Geology 27, 439-442.

Hoppe, K.A., Koch, P.L., Furutani, T.T., 2003. Assessing the preservation of biogenic strontium in fossil bones and tooth enamel. Int. J. Osteoarchaeol. $13,20-28$.

Kennedy, B.P., Folt, C.L., Blum, J.D., Chamberlain, C.P., 1997. Natural isotope markers in salmon. Nature 387, 766-767.

Kennedy, B.P., Blum, J.D., Folt, C.L., Nislow, K.H., 2000. Using natural strontium isotopic signatures as fish markers: methodology and application. Can. J. Fish. Aquat. Sci. 57, 2280-2292.

Koch, P.L., Halliday, A.N., Walter, L.M., Stearley, R.F., Huston, T.J., Smith, G.R., 1992. Sr isotopic composition of hydroxyapatite from recent and fossil salmon: the record of lifetime migration and diagenesis. Earth Planet. Sci. Lett. 108, 277-287.

Knudson, K.J., Tung, T.A., Nystrom, K.C., Price, T.D., Fullagar, P.D., 2005. The origin of the Juch'uypampa Cave mummies: strontium isotope analysis of archaeological human remains from Bolivia. J. Archaeol. Sci. 32, 903-913. 
Kosswig, C., Sözer, F., 1945. Nouveaux Cyprinodontidae de l'Anatolie centrale. Rev. Fac. Sci. Univ. Istanbul. 10 (2), 77-83.

Lécuyer, C., Grandjean, P., Sheppard, S.M.F., 1999. Oxygen isotope exchange between dissolved phosphate and water at temperatures $<135^{\circ} \mathrm{C}$ : inorganic versus biological fractionations. Geochim. Cosmochim. Acta. 63, 855-862.

Little, M.F., Barrett, K., 1976. Strontium and fluoride content of surface and inner enamel versus caries prevalence in the Atlantic Coast of the United States of America. Caries Res. 10, 297-307.

Longinelli, A., Nuti, S., 1973. Oxygen isotope measurements of phosphate from fish teeth and bones. Earth Planet Sci. Lett. 20, 337-340.

Martin, E.E., Scher, H.D., 2004. Preservation of seawater Sr and Nd isotopes in fossil fish teeth: bad news and good news. Earth Planet. Sci. Lett. 220 25-39.

Nelson, B.K., DeNiro, M.J., Schoeninger, M.J., De Paolo, D.J., 1986. Effects of diagenesis on strontium, carbon, nitrogen and oxygen concentration and isotopic composition of bone. Geochim. Cosmochim. Acta 50, 1941-1949.

Poblome, J., Sagalassos Red Slip Ware, 1999. Typology and Chronology. In: Studies in Eastern Mediterranean Archaeology 2. Brepols, Turnhout.

Price, A.D., Manzanilla, L., Middleton, W.D., 2000. Immigration and the ancient city of Teotithuacan in Mexico: a study using strontium isotope ratios in human bone and teeth. J. Archaeol. Sci. 27, 903-913.

Putzeys, T., Waelkens, M., Poblome, J., Van Neer, W., Van Thuyne, T., Kellens, N. Contextual analysis at Sagalassos, in press. In: Gutteridge, A., Swift, E. (Eds.), Objects in Context, Objects in Use: the Archaeology of Everyday Life (Late Antique Archaeology 4). Leiden, in press.

Reynolds, A.C., Betancourt, J.L., Quade, J., Patchett, P.J., Dean, J.S., Stein, J., 2005. ${ }^{87} \mathrm{Sr} /{ }^{86} \mathrm{Sr}$ sourcing of ponderosa pine used in Anasazi great house construction at Chaco Canyon, New Mexico. J. Archaeol. Sci. 32, 1061-1075.

Schweissing, M.M., Grupe, G., 2003. Stable strontium isotopes in human teeth and bone: a key to migration events of the late Roman period in Bavaria. J. Archaeol. Sci. 30, 1373-1383.

Sibbing, F.A., 1982. Pharyngeal mastication and food transport in the carp (Cyprinus carpio L.): a cineradiographic and electromyographic study. J. Morphol. 172, 223-258.

Sillen, A., 1986. Biogenic and diagenic Sr/Ca in Plio-Pleistocene fossils of the Omo Shungura Formation. Paleobiology 12, 311-323.

Simkiss, K., 1974. Calcium metabolism of fish in relation to ageing. In: Begenal, T.B. (Ed.), The Ageing of Fish. Unwin Brothers Ltd, Surrey, UK, pp. 1-12.

Tuross, N., Behrensmeyer, A.K., Eames, E.D., 1989. Sr increases and crystallinity changes in taphonomic and archaeological bone. J. Archaeol. 661-672.
Van Neer, W., De Cupere, B., Waelkens, M., 1997. Remains of local and imported fish at the ancient site of Sagalassos (Burdur Prov., Turkey). In: Waelkens, M., Poblome, J. (Eds.), Sagalassos IV. Report on the Survey and Excavation Campaigns of 1994 and 1995. Acta Archaeologica Lovaniensia Monographiae 9. Leuven University Press, Leuven, pp. 571-586.

Van Neer, W., Wildekamp, R.H., Küçük, F., Ünlüsayın, M., Waelkens, M., Paulissen, E., 2000a. Results of the 1996 survey of the fish fauna of the Aksu river and some lakes in southwestern Anatolia, and the implications for trade at Sagalassos. In: Waelkens, M., Loots, L. (Eds.), Sagalassos V. Report on the Survey and Excavation Campaigns of 1996 and 1997. Acta Archaeologica Lovaniensia Monographiae 11. Leuven, pp. 828-842.

Van Neer, W., Wildekamp, R., Waelkens, M., Arndt, A., Volckaert, F., 2000b. Fish as indicators of trade relationships in Roman times: the example of Sagalassos, Turkey. In: Mashkour, M., Choyke, A.M., Buitenhuis, H., Poplin, F. (Eds.), Archaeozoology of the Near East IV. Proceedings of the Fourth International Symposium on the Archaeozoology of Southwestern Asia and Adjacent Areas. Archaeological Research and Consultancy-Publication 32. Groningen, pp. 206-215.

Van Neer, W., Lernau, O., Friedman, R., Mumford, G., Poblome, J., Waelkens, M., 2004. Fish remains from archaeological sites as indicators of former trade connections in the Eastern Mediterranean. Paléorient 30 (1), 101-148.

Van Neer, W., Wildekamp, R.H., Küçük, F., Ünlüsayın, M., Poblome, J., Waelkens, M., in press. The 1997-1999 surveys of the Anatolian fish fauna and their relevance to the interpretation of trade at Sagalassos. In: M. Waelkens, J. Poblome (Eds.), Sagalassos VI. Report on the Survey and Excavation Campaigns of 1998, 1999 and 2000. Acta Archaeologica Lovaniensia Monographiae. Leuven, in press.

Wang, Y., Cerling, T.E., 1994. A model for fossil tooth and bone diagenesis: implications for paleodiet reconstruction from stable isotopes. Palaeogeogr. Palaeoclimatol. Palaeoecol. 107, 281-289.

White, C.D., Spence, M.W., Le, H., Stuart-Williams, Q., Schwarcz, H.P., 1998. Oxygen isotopes and the identification of geographical origins: the valley of Oaxaca versus the Valley of Mexico. J. Archaeol. Sci. 27, 643-645.

Zazzo, A., Lécuyer, C., Mariotti, A., 2004a. Experimentally-controlled carbon and oxygen isotope exchange between bioapatites and water under inorganic and microbially-mediated. Geochim. Cosmochim. Acta. 68, $1-12$.

Zazzo, A., Lécuyer, C., Sheppard, S.M.F., Grandjean, P., Mariotti, A., 2004b. Diagenesis and reconstruction of paleoenvironments: a method to restore original $\delta^{18} \mathrm{O}$ values of carbonate and phosphate from fossil tooth enamel. Geochim. Cosmochim. Acta. 68, 2245-2258. 